[This is a post-referring version]

[Accepted in Remote Sensing of Environment]

[DOI: 10.1016/j.rse.2019.111250]

[Link to the published paper: https://doi.org/10.1016/j.rse.2019.111250]

\title{
Surface albedo as a proxy for land-cover clearing in seasonally dry forests: Evidence from the Brazilian Caatinga
}

\author{
John Cunhaa, ${ }^{a}$, Rodolfo L. B. Nóbregaab,c , Iana Rufino ${ }^{d}$, Stefan Erasmie, Carlos \\ Galvao $^{d}$, Fernanda Valente ${ }^{f}$
}

\author{
${ }^{a}$ Federal University of Campina Grande, Centre for the Sustainable Development of the Semi - Arid, \\ Sumé, Brazil \\ bUniversity of Reading, School of Archaeology, Geography and Environmental Science, Reading, \\ United Kingdom \\ Imperial College London, Faculty of Natural Sciences, Department of Life Sciences, Silwood Park \\ Campus, Ascot, United Kingdom \\ dFederal University of Campina Grande, Centre for Natural Resources and Technology, Campina \\ Grande, Brazil \\ eUniversity of Gottingen, Institute of Geography, Cartography GIS \& Remote Sensing Section, \\ Goettingen, Germany \\ fUniversity of Lisbon, School of Agriculture, Forest Research Centre (CEF), Tapada da Ajuda, 1349- \\ 017 Lisbon, Portugal. \\ *Corresponding author: john.brito@ufcg.edu.br
}

\section{Abstract:}

Ongoing increase in human and climate pressures, in addition to the lack of monitoring initiatives, makes the Caatinga one of the most vulnerable forests in the world. The Caatinga is located in the semi-arid region of Brazil, and its vegetation phenology is highly dependent on precipitation, which has a high spatial and temporal variability. Under these circumstances, satellite image-based methods are valued due to their ability to uncover human-induced changes from climate effects on land cover. In this study, a time series stack of 670 Landsat images over a period of 31 years (1985-2015) was used to investigate spatial and temporal patterns of land-cover clearing (LCC) due to vegetation removal in an area of the Caatinga. We compared the performance of surface albedo (SA), the Enhanced Vegetation Index (EVI) and the Normalized Difference Vegetation Index (NDVI) and evaluated their suitability for monitoring LCC in contrast to precipitation-related variations. We applied a residual trend analysis (TSS-RESTREND), with detection of significant structural changes (breakpoints) to monthly Landsat time series. Our results show that SA was able to identify LCC with a higher accuracy (89\%) than EVI (44\%) and NDVI (46\%). The overall outcome of the study shows the benefits of using spectral indices of Landsat time series that incorporate the short-wave infrared region, such as the SA, compared to vegetation indices for the monitoring of land-cover clearing, in seasonally dry forests such as the Caatinga.

Keywords: vegetation index; time series; Landsat; land-cover change; semi-arid. 
[This is a post-referring version]

[Accepted in Remote Sensing of Environment]

[DOI: 10.1016/j.rse.2019.111250]

[Link to the published paper: https://doi.org/10.1016/i.rse.2019.111250]
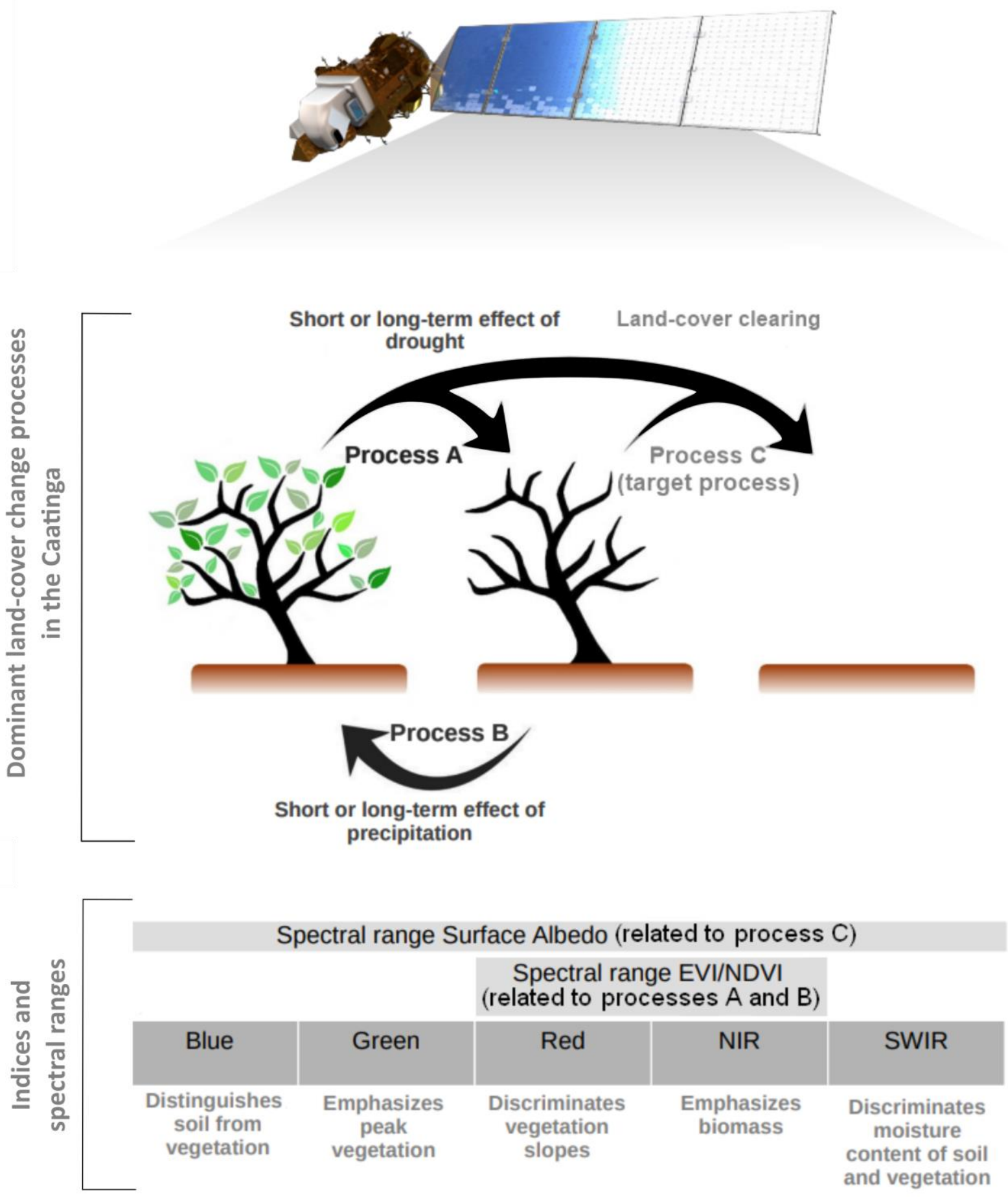
[This is a post-referring version]

[Accepted in Remote Sensing of Environment]

[DOI: 10.1016/j.rse.2019.111250]

[Link to the published paper: https://doi.org/10.1016/i.rse.2019.111250]

1. Introduction

The identification of land-cover alteration driven by human action is one of the main challenges when studying seasonally dry forests (Yang et al., 2016; Wessels et al., 2007), as it is difficult to differentiate forest from non-forest areas (Mayes et al., 2015). In these areas, vegetation greenness is strongly related to the annual precipitation averages as well as the spatial variability and shifts of the rainy season period within a year (Hein et al., 2011). This effect of temporal and spatial climatic variability often masks the human actions in seasonally dry forests, especially after long drought periods (Zhang et al., 2014), because the dry vegetation sustains an extremely low level of photosynthetic material (Jacques et al., 2014), which is usually used as an indicator of changes in land cover of forests (Eckert et al., 2015; Tucker 1979; Xu et al., 2014). However, even under these circumstances, forests lose a very large proportion of the aboveground biomass when they are cleared (IPCC, 2000). The identification of changes in terrestrial forest biomass on an annual basis is a prerequisite for improving estimates of terrestrial water, energy, and carbon sources and exchanges (Le Toan et al., 2011; Steyaert and Knox, 2008). Such assessment is possible with time-series analysis, which is a widely accepted method to identify vegetation clearing (Gómez et al., 2016; Song et al., 2014).

Long time series of satellite data are suitable to assess vegetation dynamics on a regional scale (Schucknecht et al., 2013). In this context, Landsat data is one of the most valuable sources of global observation. Owing to more than 30 years of mediumresolution and multispectral data, Landsat datasets constitute the longest continuous remotely-sensed record of the Earth's surface (Loveland and Dwyer, 2012). Despite 
[This is a post-referring version]

[Accepted in Remote Sensing of Environment]

[DOI: 10.1016/j.rse.2019.111250]

[Link to the published paper: https://doi.org/10.1016/i.rse.2019.111250]

its low temporal resolution at 16 days, earlier problems in images' absolute geolocation (Dwyer et al., 2018), and necessary adjustments of bidirectional reflectance effects (Egorov et al., 2018), Landsat imagery quality has improved. Landsat dataset structure provides information on radiometric, geometric and cloud cover quality to support temporal analysis (Wulder et al., 2016). The higher-level products are freely available through the United States Geological Survey (USGS) and allow users to retrieve surface reflectance data (Ju and Masek, 2016).

Trend analysis of indices based on visible and near-infrared (VIS-NIR, 0.4$1.1 \mu \mathrm{m})$ wavelength ranges and computed from multi-year satellite data has been widely and successfully used to monitor changes in vegetation productivity (Fensholt et al. 2012; Higginbottom and Symeonakis, 2014; De Jong et al., 2012) and land degradation (Li et al., 2016; Mariano et al., 2018). Although the effects of land-cover clearing (LCC) on climate through changes in land surface biophysical processes are well-documented, they also depend on the climate and vegetation background of the region (Liu et al., 2016; Schwinning et al., 2004). The detection of LCC in seasonally dry forests by using VIS-NIR, such as EVI and NDVI, is limited due to difficulties distinguishing deciduous vegetation from the underlying ground during the dry period (Daughtry, 2001; Jacques et al., 2014; Mayes et al., 2015; Nagler et al., 2000; Xu et al., 2014). Zhao et al. (2018) highlight that while vegetation indices are routinely used to monitor ecosystem attributes and functions such as vegetation cover and primary productivity, the remote sensing-measured surface albedo (SA) can be used to assess ecosystem status in drylands. SA is more sensitive to changes in biomass (RodríguezCaballero et al., 2015); it has been used to monitor changes in dryland ecosystems, 
[This is a post-referring version]

[Accepted in Remote Sensing of Environment]

[DOI: 10.1016/j.rse.2019.111250]

[Link to the published paper: https://doi.org/10.1016/i.rse.2019.111250]

and it is positively correlated with exposed soils (Yu et al., 2017), which are the outcome of the LCC process (Lamchin et al., 2016; Liu et al., 2016;; Karnieli et al., 2014). SA is also reported to be sensitive to seasonal phenological variations (Samain et al., 2008; Wang et al., 2017), which are caused primarily by climatic variability in dry forests.

Different statistical approaches based on satellite data have been used to distinguish the effects of climatic variability on vegetation from anthropogenic actions on land cover in seasonally dry forests (Anyamba et al., 2014; DeVries et al., 2015; Evans and Geerken, 2004; Higginbottom and Symeonakis, 2014; Ibrahim et al., 2015; Karlson and Ostwald, 2016; Leroux et al., 2017; Verbesselt et al., 2016). In most of these studies, changes in the environment are identified by using trend analysis methods that remove the seasonal cycle within the time series. Here, we highlight two of them, considering their effectiveness to detect LCC in seasonally dry forests: the RESidual TREND (RESTREND, Evans and Geerken, 2004; Li et al., 2016; Wessels et al., 2012) and the Break detection For Additive Season and Trend (BFAST, DeVries et al., 2015; Dutrieux et al., 2015; Verbesselt et al., 2012) methods. The RESTREND method is capable of coping with inter-annual rainfall variability and trends for detection of realistic levels of human-induced LCC by considering the residuals of the regression between the target variable (e.g., NDVI) and rainfall (Wessels et al., 2012). The BFAST method decomposes the time series for detecting structural changes in both the trend and seasonal components to identify changes in land cover (De Jong et al., 2012). The TSS-RESTREND (Time Series Segmentation and RESidual TREND) method (Burrell et al., 2017) combines the RESTREND and BFAST analyses by attenuating seasonal 
[This is a post-referring version]

[Accepted in Remote Sensing of Environment]

[DOI: 10.1016/j.rse.2019.111250]

[Link to the published paper: https://doi.org/10.1016/i.rse.2019.111250]

climate effects and detecting structural changes (breakpoints), and adds the Chow test (Chow, 1960) to identify the most significant breakpoint in the time series. The Chow test and the representation of the seasonal component by RESTREND are relevant mechanisms incorporated into TSS-RESTREND to overcome the limitations of the RESTREND and BFAST methods when each method is applied alone. As a result of this combination and improvement, the TSS-RESTREND method can be divided into two components: a structural change (breakpoint) detection and an overall trend estimation. While the first one is feasible to detect changes that occur abruptly, such as LCC, the latter is appropriate to identify trends that happen over a longer period of time.

In our study, we focus on the use of the structural change detection component of the TSS-RESTREND method in the Caatinga, which is a seasonally dry forest constrained by climatic and anthropogenic pressures. Located in northeastern Brazil, a region dominated by a semi-arid climate with high temporal and spatial rainfall variability (Marengo et al., 2017), the Caatinga vegetation is a heterogeneous (Rodal et al., 2008), seasonal semi-deciduous dry forest (Albuquerque et al., 2012; Brito et al., 2012), with its phenology driven by short-term rainfall patterns (Erasmi et al., 2014; Lima and Rodal, 2010). In this region, the human actions on the land cover have been related to the clearing of the vegetation, and typically occurred at small spatial scales, which can be better identified by using a higher spatial resolution (Lambin et al., 2003; Stroppiana et al., 2012). However, most vegetation studies that analyse long (> 30 years) remote sensing time series use vegetation indices at low spatial resolution, i.e., 1 to $8 \mathrm{~km}$ (Leroux et al., 2017), which is not sufficient to detect anthropogenic impacts 
[This is a post-referring version]

[Accepted in Remote Sensing of Environment]

[DOI: 10.1016/j.rse.2019.111250]

[Link to the published paper: https://doi.org/10.1016/i.rse.2019.111250]

137

138

on land cover at higher resolutions (Munyati and Mboweni, 2013), such as the ones in the Caatinga.

Our hypothesis was that the SA is a better indicator for LCC detection in seasonally dry forests, such as the Caatinga, than other vegetation indices, here represented by EVI and NDVI. Although the SA is known to show different responses between vegetated and bare soil surfaces, its use to identify LCC in dry forests has been poorly documented. We ascribe this scientific gap to the lack of global time-series datasets that provide multispectral data and to only recent developments on trend detection methods that translate the concept of abrupt LCC. In this study, this is addressed by using a 31-year spectral Landsat monthly time series applied to the structural change component of the TSS-RESTREND method in a Caatinga area that has been under a multidecadal fragmented LCC process.

2. Study area and data

2.1. Study area

The study area is located in the Brazilian Caatinga, a seasonally tropical dry forest that lies in northeastern Brazil (Fig. 1A). . Unlike most seasonally dry tropical forests that occur in isolated spots, the Caatinga spreads over a vast contiguous area, occupying ca. $910,000 \mathrm{~km}^{2}$ as the largest continuous seasonally dry tropical forest and woodland vegetation (SDTFW) in the Americas (CNUC, 2017; Linares-Palomino et al., 2011). Although it is a unique ecosystem with a high degree of biodiversity and number of endemic species (Sobrinho et al., 2016), only $7.7 \%$ of its area is under environmental protection by the Brazilian National System of Conservation Units, which is $1.3 \%$ of 
[This is a post-referring version]

[Accepted in Remote Sensing of Environment]

[DOI: 10.1016/j.rse.2019.111250]

[Link to the published paper: https://doi.org/10.1016/..rse.2019.111250]

159 restricted protection areas plus $6.4 \%$ of sustainable use areas (CNUC, 2017). The

160 Caatinga is considered the most neglected and threatened Brazilian major ecosystem

161 due to inadequate and unsustainable use of its natural resources over the past

162 decades (Moro et al., 2016). Native vegetated areas of the Caatinga have been cleared

163 mainly because of ill-planned land use, which is directly influenced by how the land is

164 used for living (Andrade-Silva et al., 2012; Araújo et al., 2007, 2010; Santos and

165 Tabarelli, 2002). In our study area, like many other parts of the Caatinga, this has been

166 commonly characterized by LCC caused by wood removal for firewood/charcoal

167 production (Leal et al., 2005; Sobrinho et al., 2016). Reforestation initiatives are rare

168 in the Caatinga and recuperation of the its vegetation in cleared areas is a challenge

169 because it may take several decades to naturally re-establish the original land cover

170 ( Araujo et al., 2007; Lima et al., 2016; Pereira et al., 2003). 
[This is a post-referring version]

[Accepted in Remote Sensing of Environment]

[DOI: 10.1016/j.rse.2019.111250]

[Link to the published paper: https://doi.org/10.1016/i.rse.2019.111250]

A )

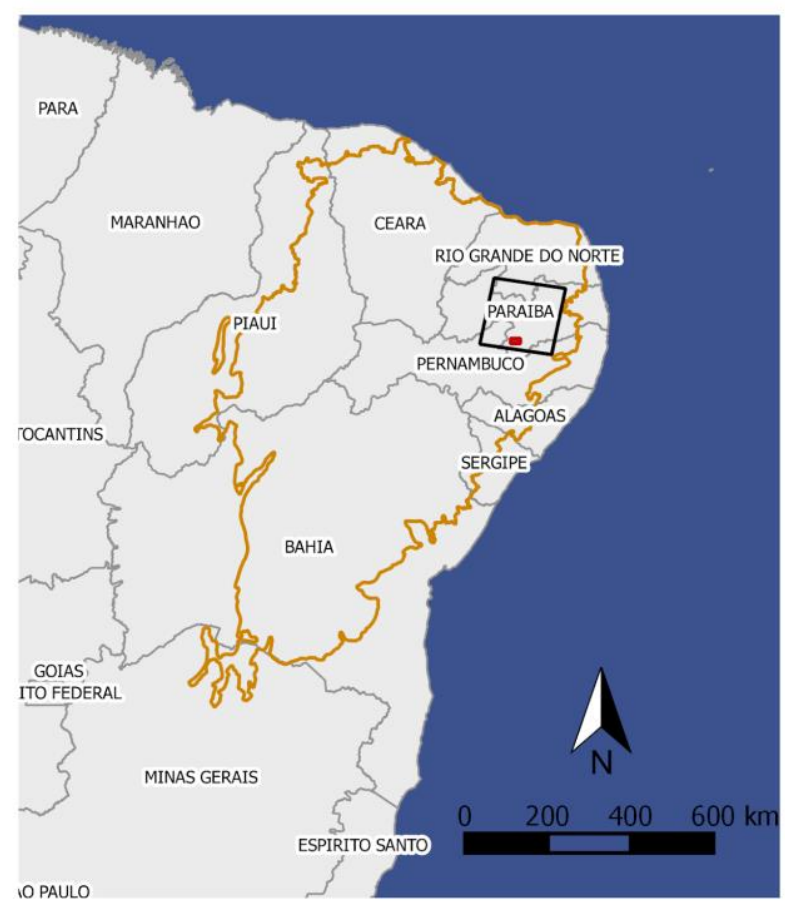

Study Area $215 / 065$ Caatinga States' limits
B )
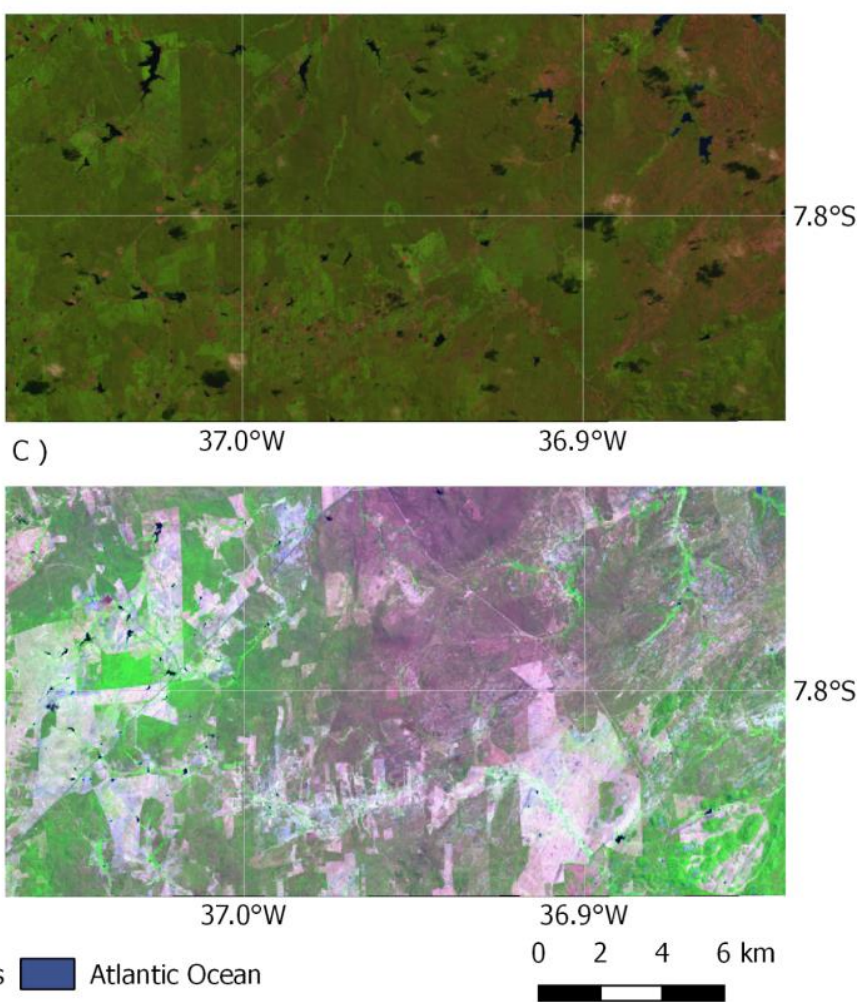

Fig. 1 - (A) Location of the Caatinga forest, Landsat scene 215/065 (path/row) and study area (Xmin: 37.07ㅇW; Xmax: 36.84ํW; Ymin: 7.86오; Ymax: 7.74ํS, WGS 84); (B) Landsat 5 false color composite (RGB to bands 4, 3 and 2) of the study area on 17/06/1984; (C) Landsat 8 false color composite (RGB to bands 5,4 and 3 ) of the same area of (B) on 06/05/2015, showing land-cover differences between the first and last years of the studied period.

Our area of study is part of the Depressão Sertaneja Meridional ecoregion of the Caatinga, which is the largest of Caatinga's eight ecoregions, occupying ca. $45 \%$ of the entire Caatinga and considered to have the most typical Caatinga phytogeographic distribution (Andrade-Lima, 1981; Velloso et al., 2001; Moro et al., 2016). The region where our study area is located, known as Cariris Velhos, was selected and used for decades for studies on hydrology and soil conservation due to its representativeness of the climate, soil, geology, vegetation and topography for the Brazilian semiarid/Caatinga region (Cadier, 1996; Nouvelot, 1974; Padilha et al., 
[This is a post-referring version]

[Accepted in Remote Sensing of Environment]

[DOI: 10.1016/j.rse.2019.111250]

[Link to the published paper: https://doi.org/10.1016/i.rse.2019.111250]

185

186

187

188

189

190

191

192

193

194

195

196

197

198

199

2016). This region is also included in one of the Caatinga's desertification nuclei, which emphasize the application and need of our study in this type of area (Perez-Marin et al., 2012). In this area, the main economic activities are livestock and subsistence farming (Belchior at al., 2017), leading to substantial LCC (Fig. 1B and C). The climate is hot semi-arid (BSh, Köppen classification) (Alvares et al., 2013), with only two distinct seasons: the very hot rainy season (from February to May) and the hot dry season (from June to January). The average annual rainfall in this region is approximately $550 \mathrm{~mm}$, with high interannual variability (coefficient of variation of approximately $30 \%$ ) and an average annual temperature of $23^{\circ} \mathrm{C}$ (Station code: 82792 , INMET, 2018). The Standard Precipitation-Evapotranspiration Index (SPEI, VicenteSerrano et al., 2010) for 12-month periods and the annual precipitation for the studied period and area are shown in Fig. 2. SPEI is a drought index based on the difference between precipitation and evapotranspiration that is usually used to detect and monitor drought periods. For the study area, the SPEI shows that the alternation between dry and wet periods have different magnitudes over the studied years. 
[This is a post-referring version]

[Accepted in Remote Sensing of Environment]

[DOI: 10.1016/j.rse.2019.111250]

[Link to the published paper: https://doi.org/10.1016/i.rse.2019.111250]

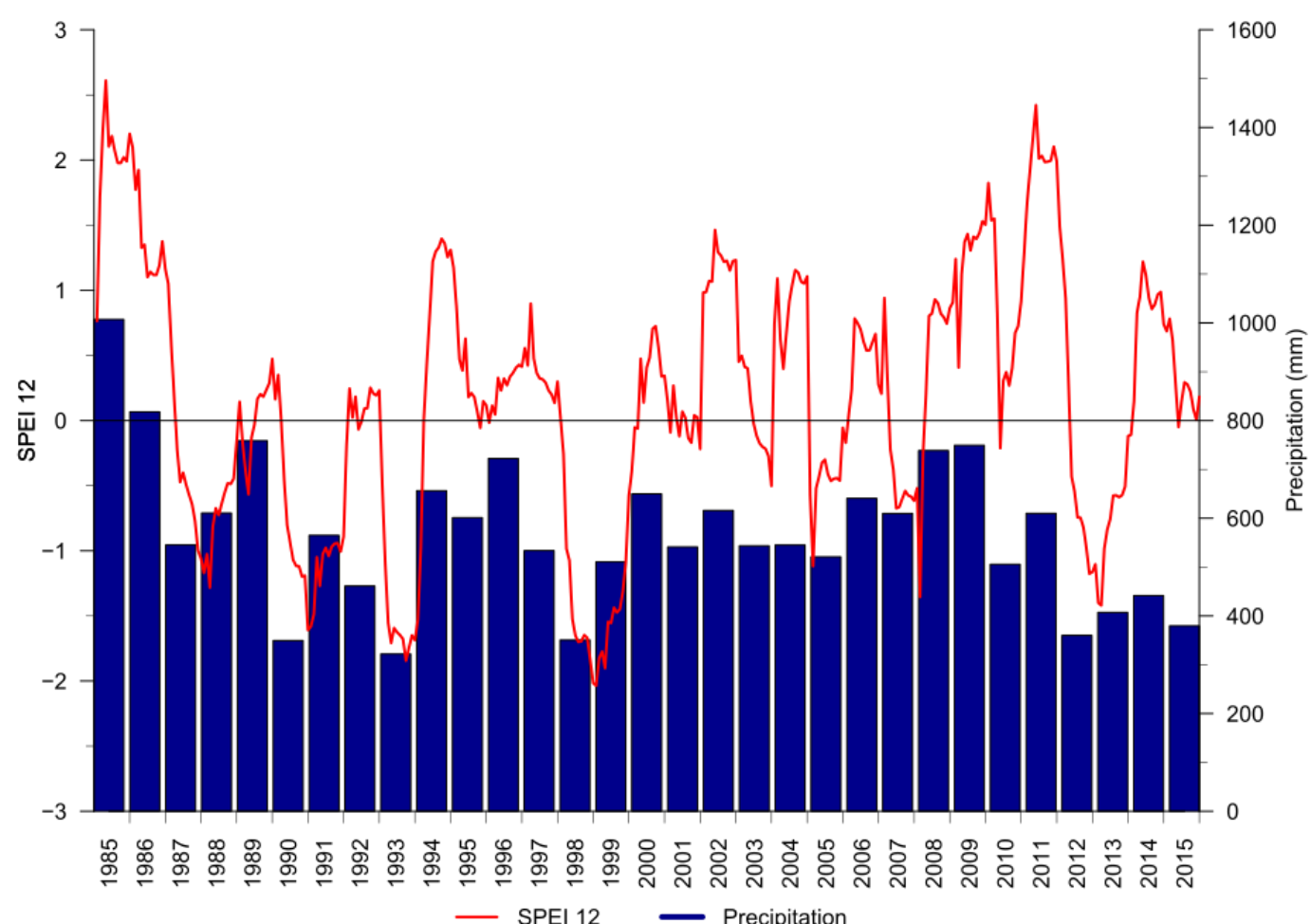

200

- SPEI 12 Precipitation

201

202

203

204

205

206

207

208

209

210

211

Fig. 2 - The 12-month Standardized Precipitation-Evapotranspiration Index - SPEI 12 (source: Beguería et al., 2017) and CHIRPS Precipitation (source: Funk et al., 2015) at geographic coordinates $36.75^{\circ} \mathrm{W}$, $7.75^{\circ} \mathrm{S}$ (WGS 84).

\subsection{Datasets}

\subsubsection{Landsat Surface Reflectance and Spectral Indices}

In this study, we used the atmospherically corrected surface reflectance (SR) from the Landsat satellites that are freely available by the United States Geological Survey (https://espa.cr.usgs.gov/). SR data are generated at 30-meter spatial resolution every 16 days. USGS provides the standard processing of SR including the Level 1 Standard Terrain Correction, resulting in ortho-rectified images of high geometric accuracy. Two different algorithms generate the SR data depending on the 
[This is a post-referring version]

[Accepted in Remote Sensing of Environment]

[DOI: 10.1016/j.rse.2019.111250]

[Link to the published paper: https://doi.org/10.1016/i.rse.2019.111250]

212

213

measuring sensor: for Landsat 5 TM and Landsat 7 ETM+ the SR data are obtained by the LEDAPS software (Masek et al., 2006), and for Landsat 8 OLI data are processed by the LaSRC algorithm (Vermote et al., 2016).

We identified 670 available Landsat images between 1985 and 2015 that cover our study area (390 from the TM sensor, 233 from the ETM+ and 47 from the OLI). For our analysis we used the Landsat Surface Reflectance Quality Assessment (pixel_qa band) to consider only clear pixels (values 66 and 130 for Landsat 5 and 7, or 322 and 386 for Landsat 8, USGS, 2018a,b), which represented in average 307 clear pixels per grid cell for the 31-year time series.

The identification of LCC was obtained by using time series of NDVI (Tucker, 1979), EVI (Huete et al.,1997, 2002) and surface albedo (SA) (Shuai et al., 2014; Wang et al., 2016). For each Landsat image, NDVI, EVI and SA were calculated using Eqs. (1) to (3).

$N D V I=\frac{\rho_{N I R}-\rho_{R E D}}{\rho_{N I R}+\rho_{R E D}}$

$E V I=2.5 \times \frac{\rho_{N I R}-\rho_{R E D}}{\rho_{N I R}+6 \times \rho_{R E D}-7.5 \times \rho_{B L U E}+1}$

$S A=b_{B L U E} \times \rho_{B L U E}+b_{G R E E N} \times \rho_{G R E E N}+b_{R E D} \times \rho_{R E D}+b_{N I R} \times \rho_{\text {NIR }}+b_{\text {SWIR1 }} \times \rho_{S W I R 1}+$ $b_{S W I R 2} \times \rho_{S W I R 2}+b_{0}$

where $\rho$ and $\mathrm{b}$ are the surface bidirectional reflectance values and their corresponding conversion coefficients for the six non-thermal Landsat bands, i.e., blue, green, red, NIR and the two shortwave infrared (SWIR1 and SWIR2) bands. Table 1 shows the $b$ values of several spectral bands of the three satellites used in this study. 
[This is a post-referring version]

[Accepted in Remote Sensing of Environment]

[DOI: 10.1016/j.rse.2019.111250]

[Link to the published paper: https://doi.org/10.1016/i.rse.2019.111250]

235

236

237

Table 1 - Band conversion coefficients used to calculate shortwave albedo for the different Landsat data.

\begin{tabular}{lccccccc}
\hline \multicolumn{1}{c}{ Sensor } & $b_{\text {BLUE }}$ & $b_{\text {GREEN }}$ & $b_{\text {RED }}$ & $b_{\text {NIR }}$ & $b_{\text {SWIR } 1}$ & $b_{\text {SWIR2 }}$ & $b_{0}$ \\
\hline Landsat-5 TM & 0.3206 & 0 & 0.1572 & 0.3666 & 0.1162 & 0.0457 & -0.0063 \\
& & & & & & & \\
Landsat-7 ETM+ & 0.3141 & 0 & 0.1607 & 0.3694 & 0.1160 & 0.0456 & -0.0057 \\
Landsat-8 OLI & 0.2453 & 0.0508 & 0.1804 & 0.3081 & 0.1332 & 0.0521 & 0.0011
\end{tabular}

The highest values of the vegetation indices are found in vegetated areas, while the lowest values occur in areas of bare soil (Mariano et al., 2018; Rodríguez-Caballero et al., 2015; Zhao et al. 2018). As SA has an inverse behaviour of vegetation indices, we used its complement to one (1 - SA) in the simulations, thus ensuring a pattern of responses to LCC that corresponds to that of the vegetation indices EVI and NDVI.

Flood (2013) showed that the medoid (a multi-dimensional analogue of the median) is a reliable measure to produce representative temporal image composites. In this study, we used the median to reduce the initial time series (SA, EVI and NDVI) to monthly composite images. Missing values were gap-filled by linear interpolation. Further, a linear Savitzky-Golay filter was applied (Cao et al., 2018; Chen et al., 2004; Savitzky and Golay, 1964), with a five-month half-width smoothing window in order to reduce the noise caused by atmospheric variability. 
[This is a post-referring version]

[Accepted in Remote Sensing of Environment]

[DOI: 10.1016/j.rse.2019.111250]

[Link to the published paper: https://doi.org/10.1016/i.rse.2019.111250]

251

252

253

254

255

256

257

258

259

260

261

262

263

264

265

266

267

268

269

270

271

272

\subsubsection{Precipitation}

The precipitation data used in this work were obtained from the Climate Hazards group InfraRed Precipitation with Stations (CHIRPS) dataset (Funk et al., 2015; Katsanos et al., 2016). CHIRPS is a near-global, very high spatial resolution $\left(0.05^{\circ}\right.$ grid) precipitation product developed for monitoring environmental changes over land (Funk et al., 2015), which exhibited correlations ranging from 0.87 to 0.93 with rain gauge observations in the Caatinga (Paredes-Trejo et al., 2017). We used monthly precipitation data from October 1983 to December 2015.

3. Methods

\subsection{TSS-RESTREND}

The TSS-RESTREND method proposed by Burrell et al. (2017), combines the RESTREND technique (Evans and Geerken, 2004) and the BFAST methodology (Verbesselt et al., 2012, 2010), allowing a better and more accurate detection of structural changes in the ecosystems. Prior to the application of trend analysis, it is frequently necessary to remove the influence of exogenous random factors (e.g., rainfall, temperature) that, in addition to time and space, has a considerable effect on the response variable. The removal process, either by parametric (e.g., regression) or nonparametric (e.g., LOWESS) methods, reduces the variability of the studied variable and increases the power to detect changes in it (Helsel and Hirsch, 2002; Schertz et al., 1991). In remote sensing, a similar procedure has been applied for land-cover analysis. The RESTREND method analyses the temporal trends in the vegetation precipitation relationship (VPR) residuals from a linear regression of the NDVI on the 
[This is a post-referring version]

[Accepted in Remote Sensing of Environment]

[DOI: 10.1016/j.rse.2019.111250]

[Link to the published paper: https://doi.org/10.1016/i.rse.2019.111250]

accumulated precipitation along a time period (Evans and Geerken, 2004). In Burrell et al. (2017), VPR is obtained for two sets of information: complete NDVI time series (CTS-NDVI) and annual maximum NDVI. In both cases, the linear regression uses the Optimal Precipitation Accumulated (OPA) calculated on a per-pixel basis by an exhaustive search algorithm, which combines different accumulation periods and lag times. In our study, the OPA uses the CHIRPS precipitation data for accumulation periods of $1-12$ months and lag times of $0-3$ months, resulting in an increase of 15 months at the beginning of the precipitation series. The optimum VPR is established by finding the highest correlation coefficients between OPA and CTS-NDVI and between OPA and annual maximum NDVI.

TSS-RESTREND uses annual VPR to exclude pixels that do not meet the criteria to use the RESTREND method, i.e., a VPR that is significant, positive and consistent with time (Wessels et al., 2012), and a gradual and consistent or monotonic residuals' trend (Jamali et al., 2015), and then applies BFAST to CTS-VPR residuals using the remaining pixels. The application of the BFAST method (Verbesselt et al., 2010) returns a list of potential breakpoints that are analysed in a following step by the Chow test (Chow, 1960) to determine if there is a significant breakpoint. After identifying significant breakpoints, TSS-RESTREND calculates the significance of each identified change and identifies the most significant breakpoint, if it exists, as the structural change. More details on the TSS-RESTREND method can be found in Burrell et al. $(2017 ; 2018)$.

In our study, we applied the structural change (breakpoint) detection component of the TSS-RESTREND method using the TSS.RESTREND package (Burrell et al., 
[This is a post-referring version]

[Accepted in Remote Sensing of Environment]

[DOI: 10.1016/j.rse.2019.111250]

[Link to the published paper: https://doi.org/10.1016/i.rse.2019.111250]

296

297

298

299

300

301

302

303

304

305

306

307

308

309

310

311

312

313

314

315

2017; https://cran. r-project.org/package=TSS.RESTREND) for the $R$ software environment (R Core Team, 2017). Although this method was initially used with NDVI data (Burrell et al., 2017), we additionally applied it to SA and EVI.. The original TSS.RESTREND package was adapted to receive raster files as input.

\subsection{Verification Methodology}

The performance of the TSS-RESTREND method was evaluated at both temporal and spatial levels. For each of the selected spectral indices and pixel, the year of the most significant breakpoint was registered and compared with the actual LCC year in order to evaluate the performance of SA, EVI and NDVI. The actual (true) year of LCC was determined by visual analysis of RapidEye images from 2015, which are freely available for academic use through the Brazilian Ministry of the Environment (http://geocatalogo.mma.gov.br/), Landsat images (false color composite) and satellite data from Google Earth Pro (https://earth.google.com/).

The validation dataset used in this work was built using a two-step procedure. First, a detailed visual survey of recent (2015) RapidEye images allowed the identification of several target areas where the original land cover had changed by the complete removal of the vegetation (land-cover clearing). Then, Landsat images and Google Earth Pro imagery were examined to determine the exact year of the LCC. Both products provided at least one cloud-free composite image per year for the study period and area at the altitude of visualization of $20 \mathrm{~km}$. Additionally, several places that had no visible human impact and that kept their original vegetation cover were chosen as validation pixels. In October 2017, field visits to the study area were conducted to confirm the land-cover status. Three different types of areas were 
[This is a post-referring version]

[Accepted in Remote Sensing of Environment]

[DOI: 10.1016/j.rse.2019.111250]

[Link to the published paper: https://doi.org/10.1016/i.rse.2019.111250]

included in the validation dataset (Fig. 3): 1) 45 target areas of $120 \mathrm{~m}$ buffer each (ca. 80 pixels), 31 exhibit LCC in the period $1985-2015$ and 14 show a preserved natural vegetation; 2) a small region of $4.5 \mathrm{~km}^{2}$ that has undergone a well-delimited time-space land-cover clearing process over the 2003-2012 period, hereafter referred to as "Subset I"; and 3) a region of $42 \mathrm{~km}^{2}$ that has undergone a LCC process during 19852015, hereafter referred to as "Subset II".

For each of the 45 selected target areas, the areal median of each spectral index was calculated and the TSS-RESTREND was applied to the new generated time series. From its outputs, only the results from the structural change detection component were kept, namely the number of breakpoints and the estimate and confidence interval of the date for each detected breakpoint (hereafter referred to as estimated LCC year). Based on the statistical theory proposed by Bai (1997), the breakpoints analysis implemented in the BFAST module (Verbesselt et al., 2010, Zeileis et al., 2002) calculates confidence intervals for the change-point date with less restrictive assumptions than those required by the usual parametric methods (i.e., independent and homogeneous normal errors). Due to these characteristics, these intervals were used in the validation of our results. The output of the TSS-RESTREND method was compared with the actual year of LCC. The accuracy of all indices was computed as the ratio of the number of target areas that had their LCC (or the lack thereof) correctly estimated to the total number of target areas. Other metrics related to the lack of ability of detecting LCC when it actually took place and vice versa were also evaluated. These metrics were divided into the following categories: a) detected true, when the actual LCC year was contained in the $95 \%$ confidence interval of the 
[This is a post-referring version]

[Accepted in Remote Sensing of Environment]

[DOI: 10.1016/j.rse.2019.111250]

[Link to the published paper: https://doi.org/10.1016/i.rse.2019.111250]

342 estimated LCC year, or when LCC was not detected and an actual LCC process did

343 not occur; b) time wrong, when the actual LCC year did not lie in the $95 \%$ confidence

344 interval of the estimated LCC year; c) false negative, when the LCC was not detected,

345 but it has actually occurred, and; d) false positive, when LCC was detected, but it has

346 not occurred.

347 The Subset I illustrates the process of fragmentation of land-cover clearing and

348 the ability of the proposed methodology to identify these sequential changes (Fig. 3).

349 Within this area, pixels exhibiting land clearing in the same year were encompassed

350 within the same patch. In addition, the median was calculated for the estimated LCC

351 year of all pixels within each patch, providing a quantitative comparison with the actual

352 LCC year. The median rather than the mean was used as a summary measure

353 because it is a robust statistic of central tendency, less influenced by extreme values

354 (outliers). Additionally, the Kendall rank correlation coefficient $(\tau)$ between the median

355 of the estimated LCC year and the actual vegetation clearing year for the nine patches

356 was also calculated and its statistical significance tested. Subset II was used in a visual

357 analysis between the estimate breakpoint dates detected by SA time series and

358 Landsat images (false color composite) at 5-year intervals. 
[This is a post-referring version]

[Accepted in Remote Sensing of Environment]

[DOI: 10.1016/j.rse.2019.111250]

[Link to the published paper: https://doi.org/10.1016/i.rse.2019.111250]

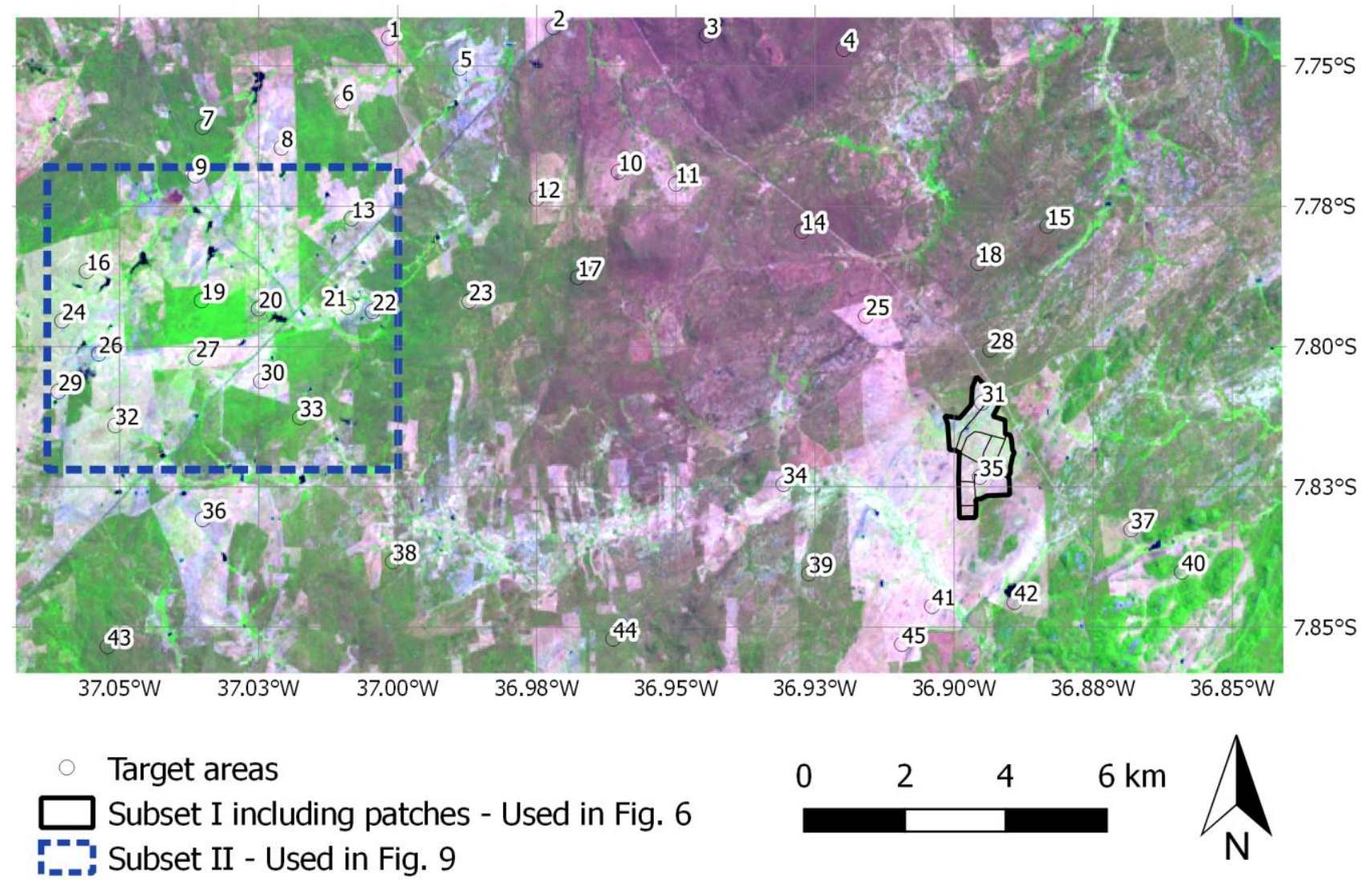

Fig. 3 - Location of the validation sites in the study area: 45 target areas (numbered, 31 target areas

where a LCC actually occurred and 14 areas with preserved natural vegetation), the Subset I that had a sequential land-cover clearing process during 2003-2012 and the Subset II validation area. Source: Landsat 8 false color composite (RGB to bands 5, 4 and 3).

4. Results

Whereas values ranged between 0.08 and 0.57 for EVI and 0.13 and 0.73 for NDVI,

SA values varied only between 0.10 and 0.25 . Moreover, the number of the breakpoints detected by using EVI and NDVI is greater than that with SA (Fig. 4). Most of the 
[This is a post-referring version]

[Accepted in Remote Sensing of Environment]

[DOI: 10.1016/j.rse.2019.111250]

[Link to the published paper: https://doi.org/10.1016/i.rse.2019.111250]

breakpoints occurred during a drought period (SPEI <-1, cf. Fig. 2), especially for EVI and NDVI.
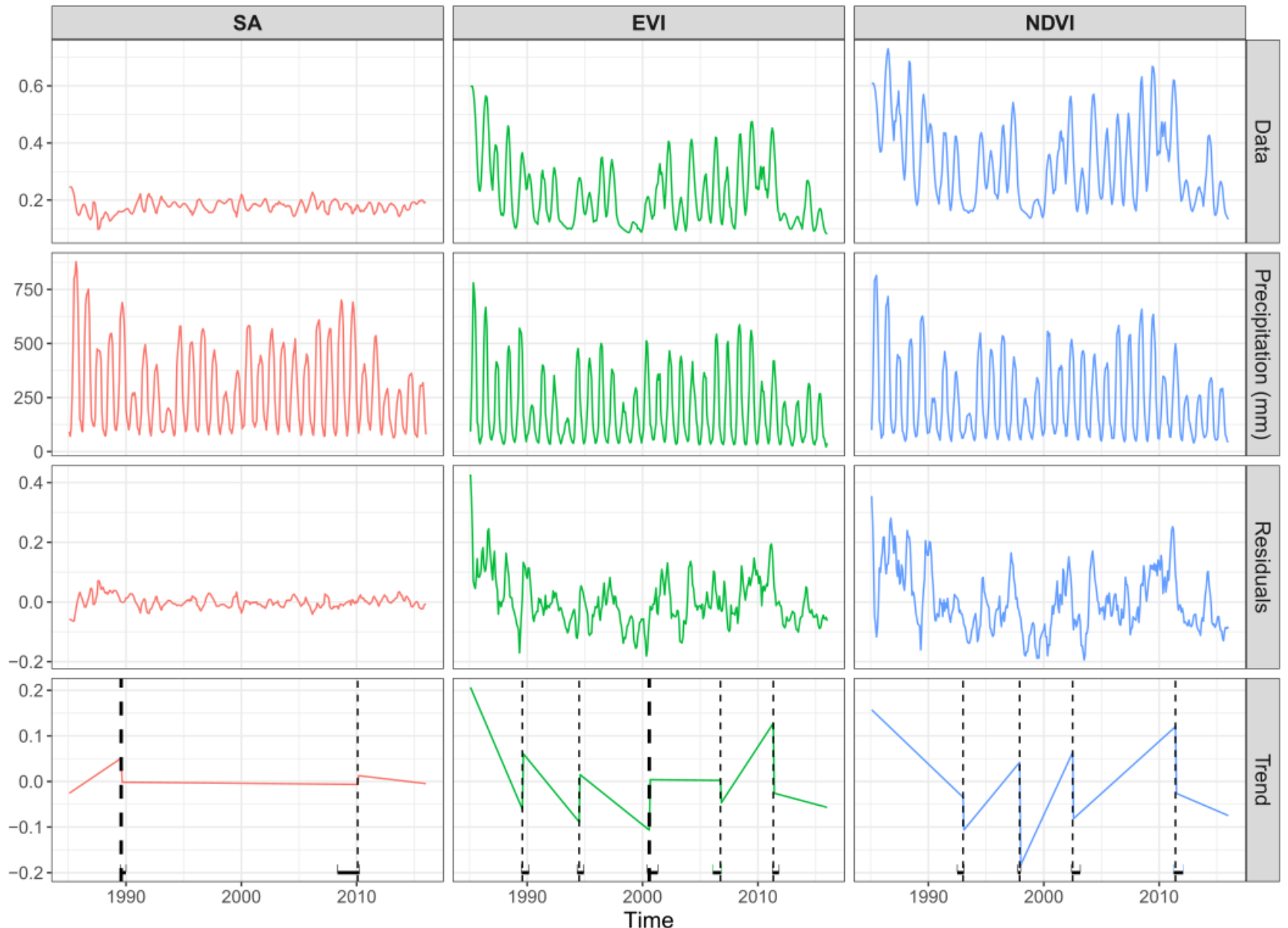

Fig. 4: TSS-RESTREND structural change detection outputs for the target area 22. Top row panel shows SA, EVI and NDVI entire time series data, whereas the next panel has complete OPA time series, followed by monthly residuals of OPA, and Trend to each time series spectral indices. In the Trend panel, vertical lines represent breakpoints and the bold vertical line the most significative breakpoint.

In general, despite the smallest number of breakpoints identified by SA, this index showed the best performance in detecting LCC on an annual scale and had on average the narrowest $95 \%$ confidence interval for the breakpoint date when compared to that of EVI and NDVI (Fig. 5, Table 2). The SA detected $89 \%$ of the LCC (being the sum of detected true and time wrong), while EVI and NDVI detected only $44 \%$ and 
[This is a post-referring version]

[Accepted in Remote Sensing of Environment]

[DOI: 10.1016/j.rse.2019.111250]

[Link to the published paper: https://doi.org/10.1016/i.rse.2019.111250]

383

384

385

A)

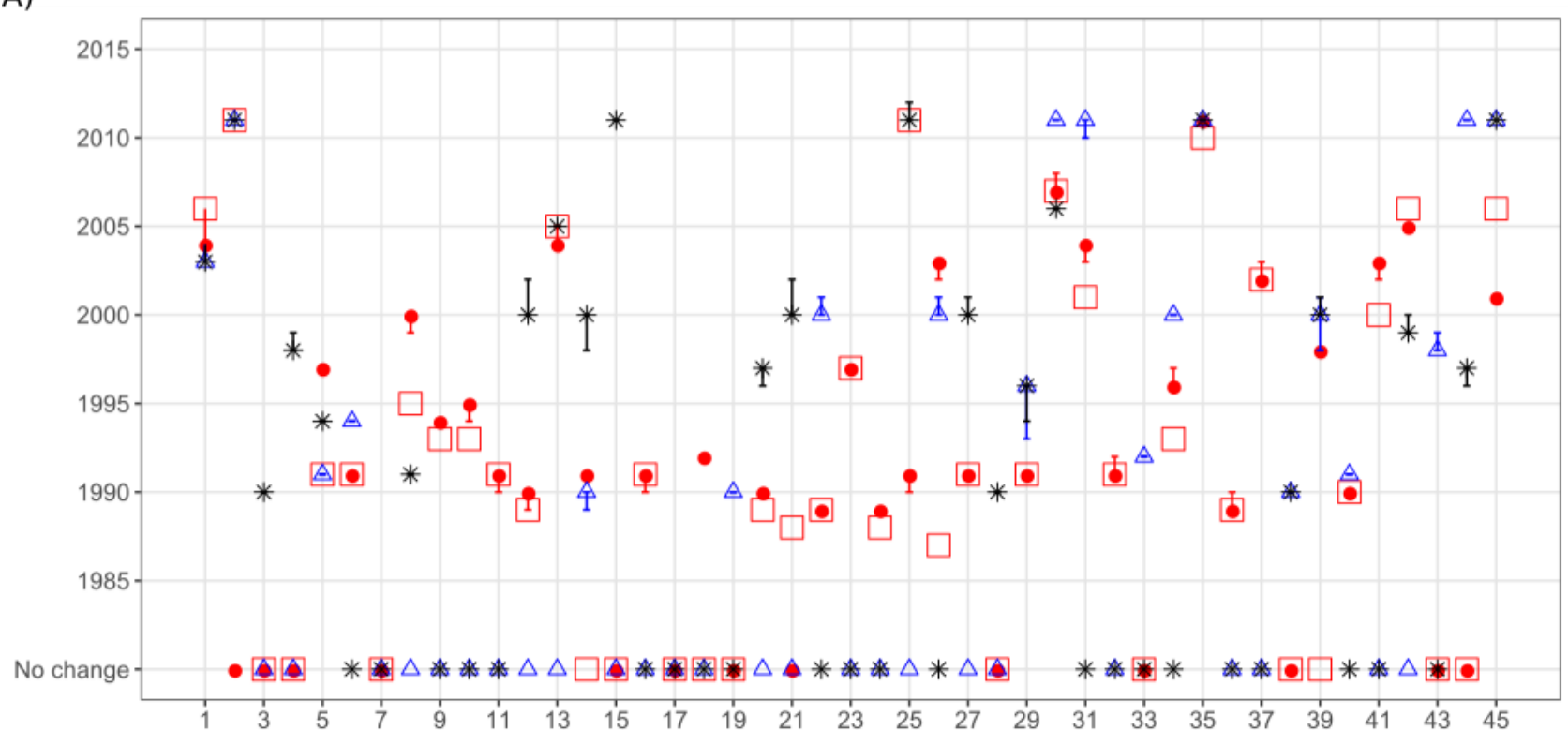

B)

$\square$ Actual LCC year $\bullet$ SA $\triangle \mathrm{EVI} * \mathrm{NDVI}$

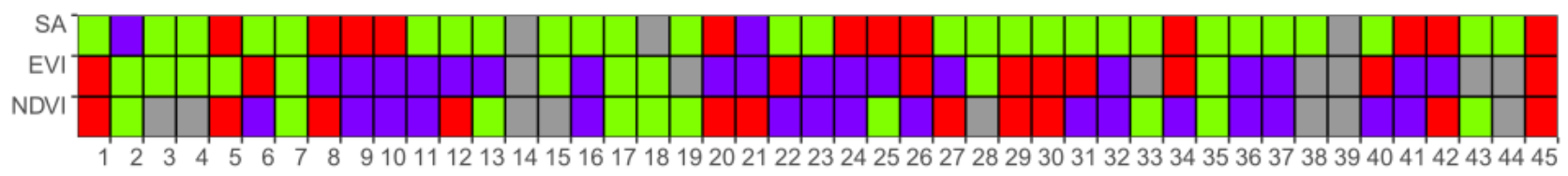

Detected True
False Negative

False Positive

Fig. 5 - Estimated and actual year of land-cover clearing for SA, EVI and NDVI for the 45 target areas: A) Description and B) Summary

The subset I is a region with LCC between 2001 and 2012 (highlighted in Fig. 3 within the black polygon) and it was used to analyse the results in more detail (Fig. 6). This region contains two target areas, which exhibit contrasting performances: the LCC in the target area 31 was only detected by the SA, while the LCC for target area 35 was correctly detected by all three indices (Fig 5). Within the polygon, the main 
[This is a post-referring version]

[Accepted in Remote Sensing of Environment]

[DOI: 10.1016/j.rse.2019.111250]

[Link to the published paper: https://doi.org/10.1016/i.rse.2019.111250]

395

396

397

398

399

400

401

402

403

404

405

406

407

408

409

changes in land cover occurred between 2003 and 2012, which is shown by nine patches. Each patch is identified by the actual LCC year that is dominant among its pixels. The analysis of these patches revealed that when EVI and NDVI were used, a substantial number of pixels (sometimes $>40 \%$ ) were categorized as false negative (Fig. 7A). This situation was particularly relevant in the patches where the LCC occurred in 2003, 2004, 2008 and 2010 (Fig. 6 and 7A). In contrast, results obtained with SA showed that false negative pixels were less than $10 \%$ for all patches (Fig. 7A) and exhibited an overall better accuracy in identifying the actual LCC year (Fig. 7B). In fact, for the nine patches, the median of the estimated LCC year by SA was closer to the actual LCC year than those obtained with EVI and NDVI (Fig. 7B). This was also confirmed by Kendall's correlation coefficient $(\tau)$ between actual and estimated LCC years: SA had the highest value $(\tau=0.86)$ with the highest significance $(p<0.01)$.

Table 2 - Number of validation target areas in the different categories (and percentage of the total) according to the results of the TSS-RESTREND method applied with the three spectral indices (Fig. 5), average confidence interval amplitude and average number breakpoint detected.

\begin{tabular}{ccccccc}
\hline Index & $\begin{array}{c}\text { Detected } \\
\text { True }\end{array}$ & Time Wrong & $\begin{array}{c}\text { False } \\
\text { Positive }\end{array}$ & $\begin{array}{c}\text { False } \\
\text { Negative }\end{array}$ & $\begin{array}{c}\text { Average } \\
95 \% \\
\text { Confidence } \\
\text { Interval } \\
\text { amplitude } \\
\text { (in months) }\end{array}$ & $\begin{array}{c}\text { Average } \\
\text { number of } \\
\text { Breakpoints } \\
\text { Detected }\end{array}$ \\
\hline SA & $28(62 \%)$ & $12(27 \%)$ & $3(7 \%)$ & $2(4 \%)$ & 8.7 & 2.8 \\
EVI & $10(22 \%)$ & $10(22 \%)$ & $7(16 \%)$ & $18(40 \%)$ & 10.9 & 3.5 \\
NDVI & $10(22 \%)$ & $11(24 \%)$ & $8(18 \%)$ & $16(36 \%)$ & 11.6 & 4.0 \\
\hline
\end{tabular}


[This is a post-referring version]

[Accepted in Remote Sensing of Environment]

[DOI: 10.1016/j.rse.2019.111250]

[Link to the published paper: https://doi.org/10.1016/i.rse.2019.111250]

413

414

415

416

417

418

419

420

421

422 indices.

SA

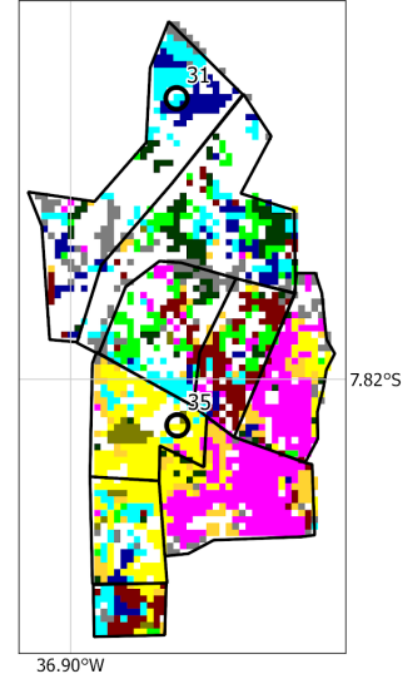

423

424

425

426

427

428
EVI

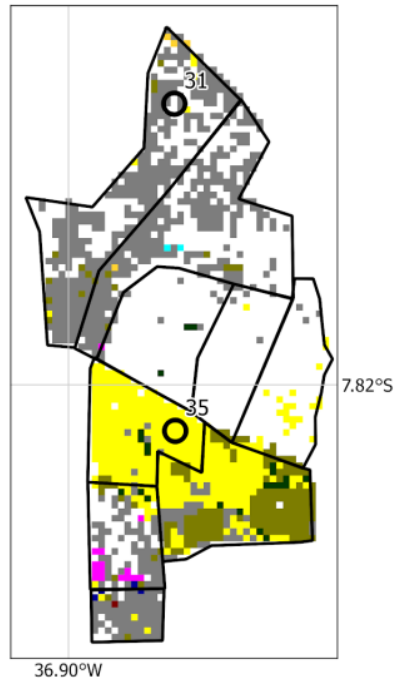

2003

2004

(Fig. 7B and 8). Although there is a higher dispersion of the SA results than those of

$\mathrm{EVI}$ and NDVI, the median of the detected year of change is closer to the observed date in the former index. Furthermore, while the validation polygon is hardly identified in the output raster of these two vegetation indices, it is quite well-defined in the SA raster (Fig. 6). This result is a consequence of the quite different performance of the TSS-RESTREND method to detect LCC when applied to time series of the three

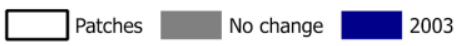

NDVI

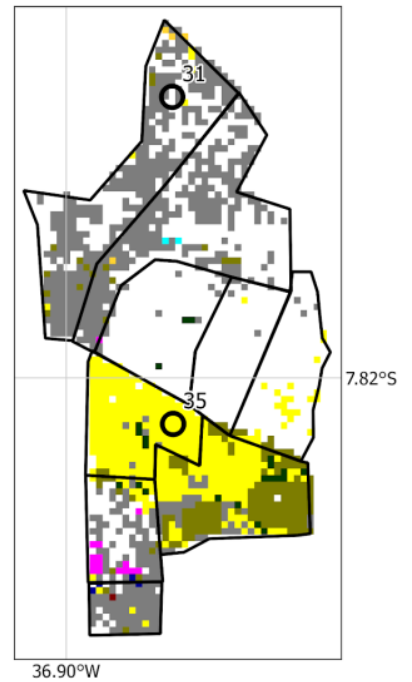

2007
Actual LCC Year

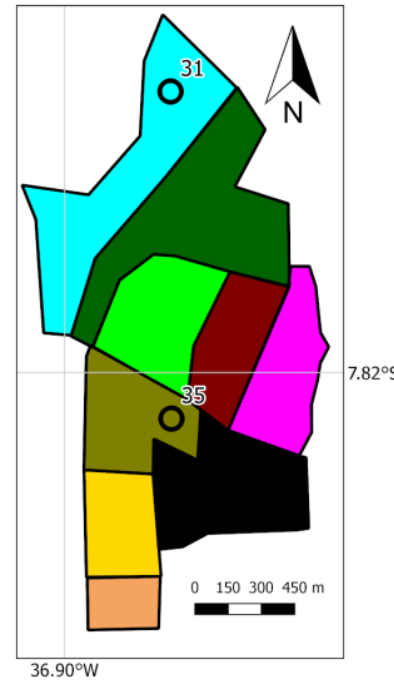

2010 2012

Fig. 6 - Polygon with selected patches showing the detected breakpoint years of LCC for SA, EVI, NDVI and actual LCC year.

Visual comparison of the breakpoint raster for the subset II with Landsat images false color composite shows that the SA has some difficulty in identifying the correct year of clearing when it occurs during the initial and final years of the time series (1985- 
[This is a post-referring version]

[Accepted in Remote Sensing of Environment]

[DOI: 10.1016/j.rse.2019.111250]

[Link to the published paper: https://doi.org/10.1016/i.rse.2019.111250]

4291990 and 2010-2015, Fig. 9). On the other hand, SA performed well for the small 430 vegetation areas that remain unchanged during the study period (e.g., the region were 431 the target area 19 is located), whereas with EVI and NDVI lower accuracy can be 432 interpreted as an effect of adverse climate period or degradation on the vegetation. 433 Although this ability of the NDVI and EVI might be useful to detect intra-annual changes 434 and trends of degradation of the vegetation, we have only assessed the skill of the 435 these indices to detect LCC.
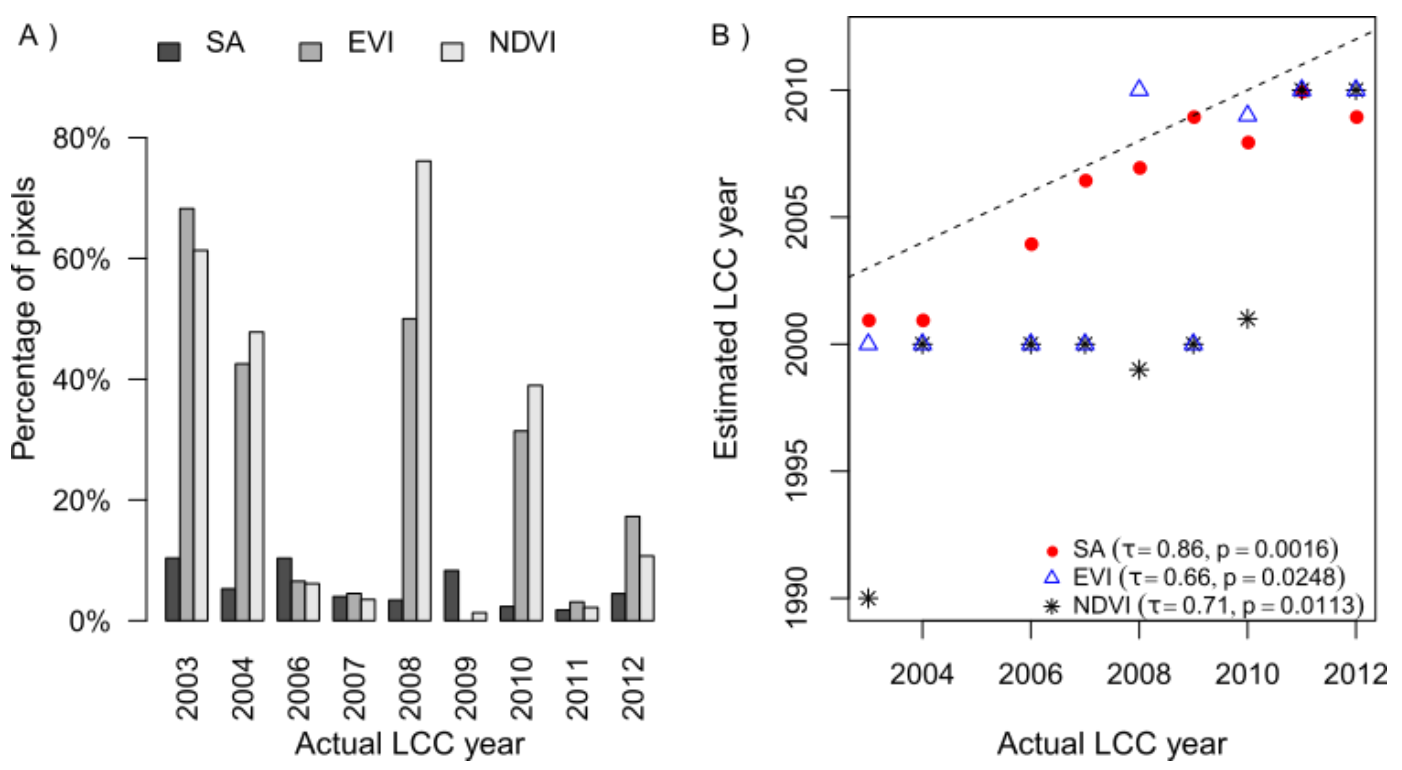

Fig. 7 - Observed change year of land-cover clearing of the different patches compared with the results obtained with the TSS-RESTREND method for the SA, NDVI and EVI: A) percentage of the total number of pixels in each patch where the method output was classified as False Negative; B) median of the detected breakpoints within each of the nine patches for all the pixels where LCC was detected. The dotted line is the $1: 1$ line and $\tau$ is the Kendall rank correlation coefficient. 
[This is a post-referring version]

[Accepted in Remote Sensing of Environment]

[DOI: 10.1016/j.rse.2019.111250]

[Link to the published paper: https://doi.org/10.1016/i.rse.2019.111250]
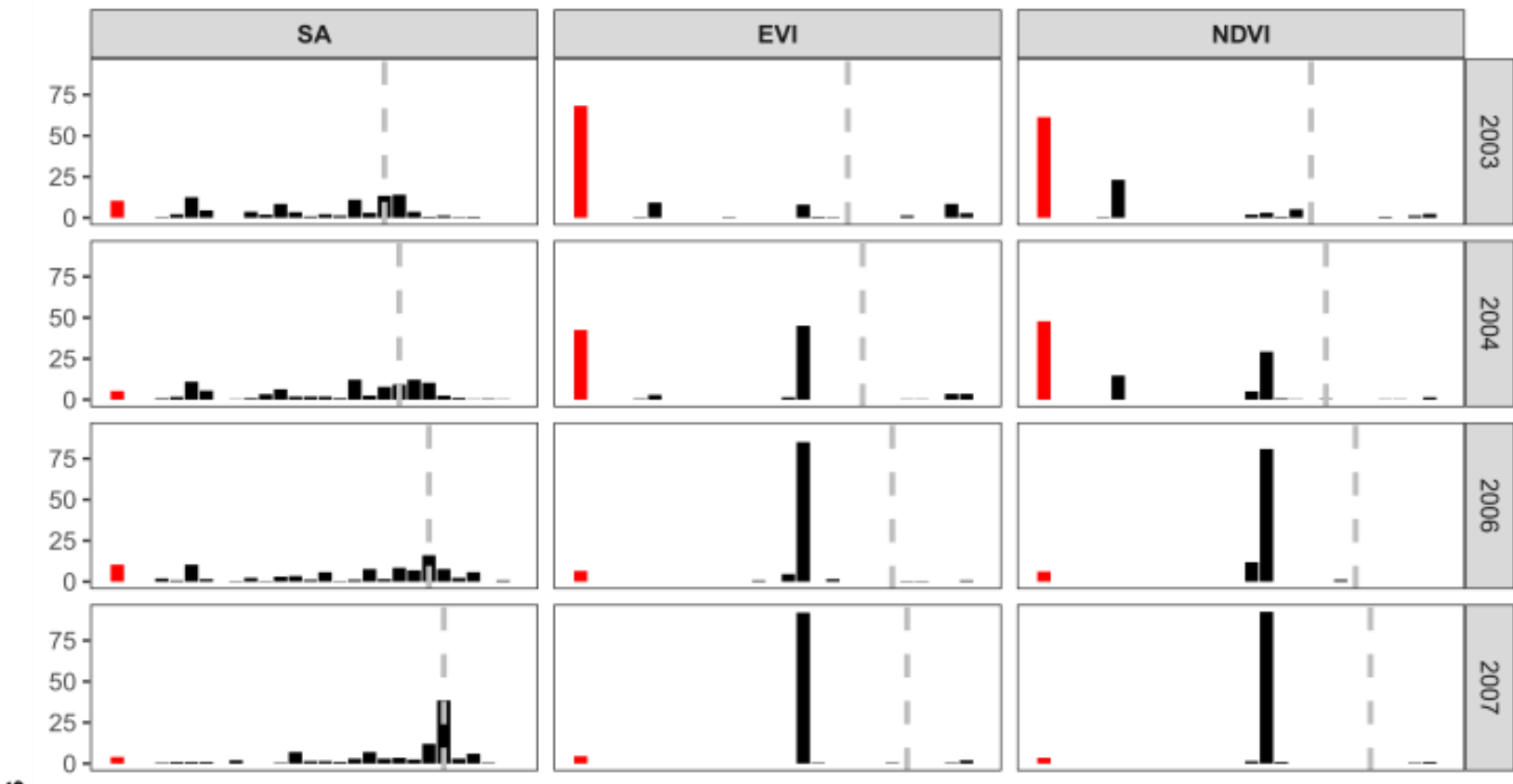

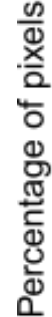
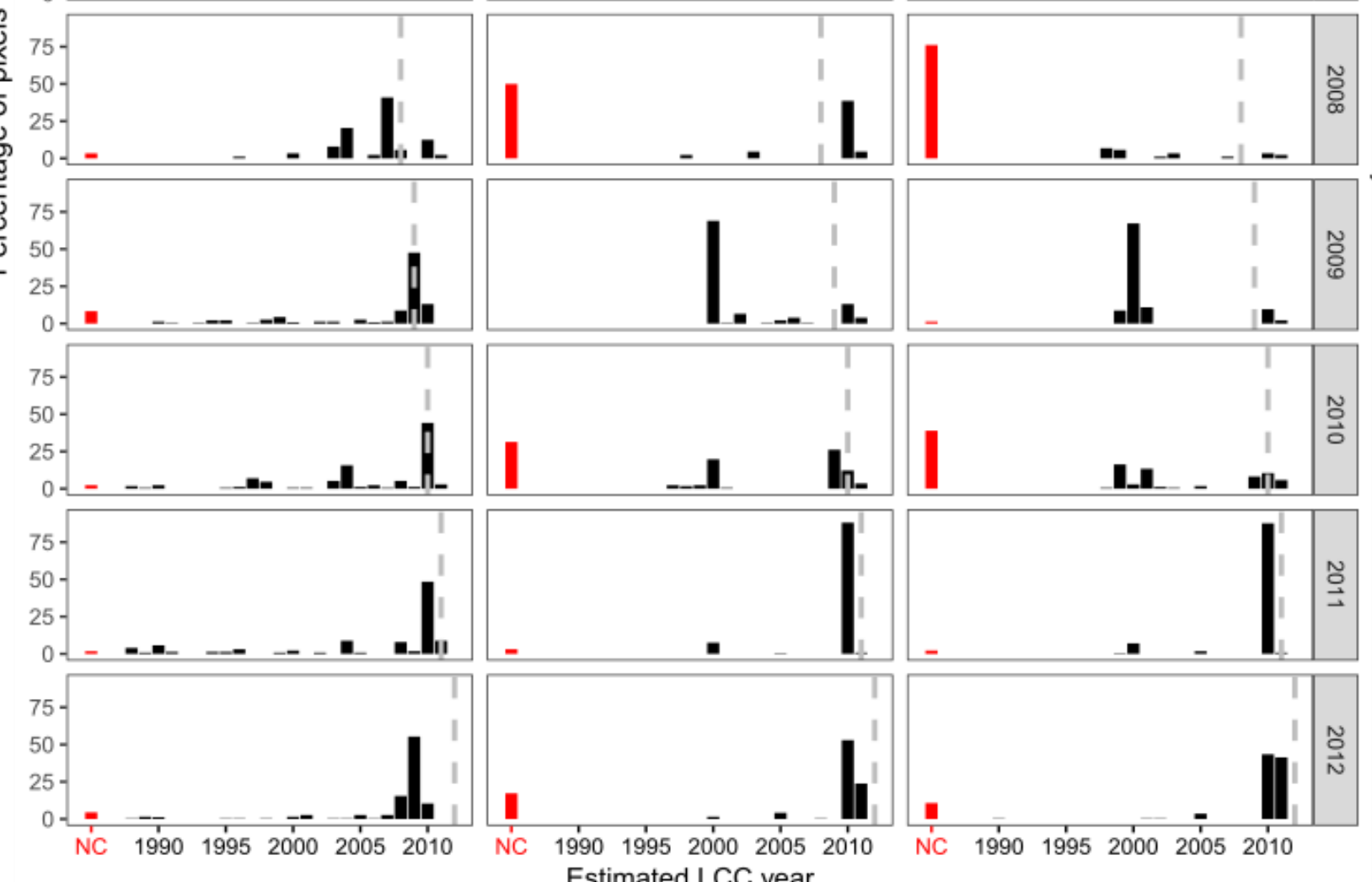

Estimated year

443 Fig. 8 - Bar plots of the detected breakpoint year obtained by the TSS-RESTREND method applied to the three spectral indices (SA, EVI and NDVI) for the different patches of the Subset I validation polygon. 
[This is a post-referring version]

[Accepted in Remote Sensing of Environment]

[DOI: 10.1016/j.rse.2019.111250]

[Link to the published paper: https://doi.org/10.1016/i.rse.2019.111250]

447 year. Red bars correspond to pixels where no change was detected.
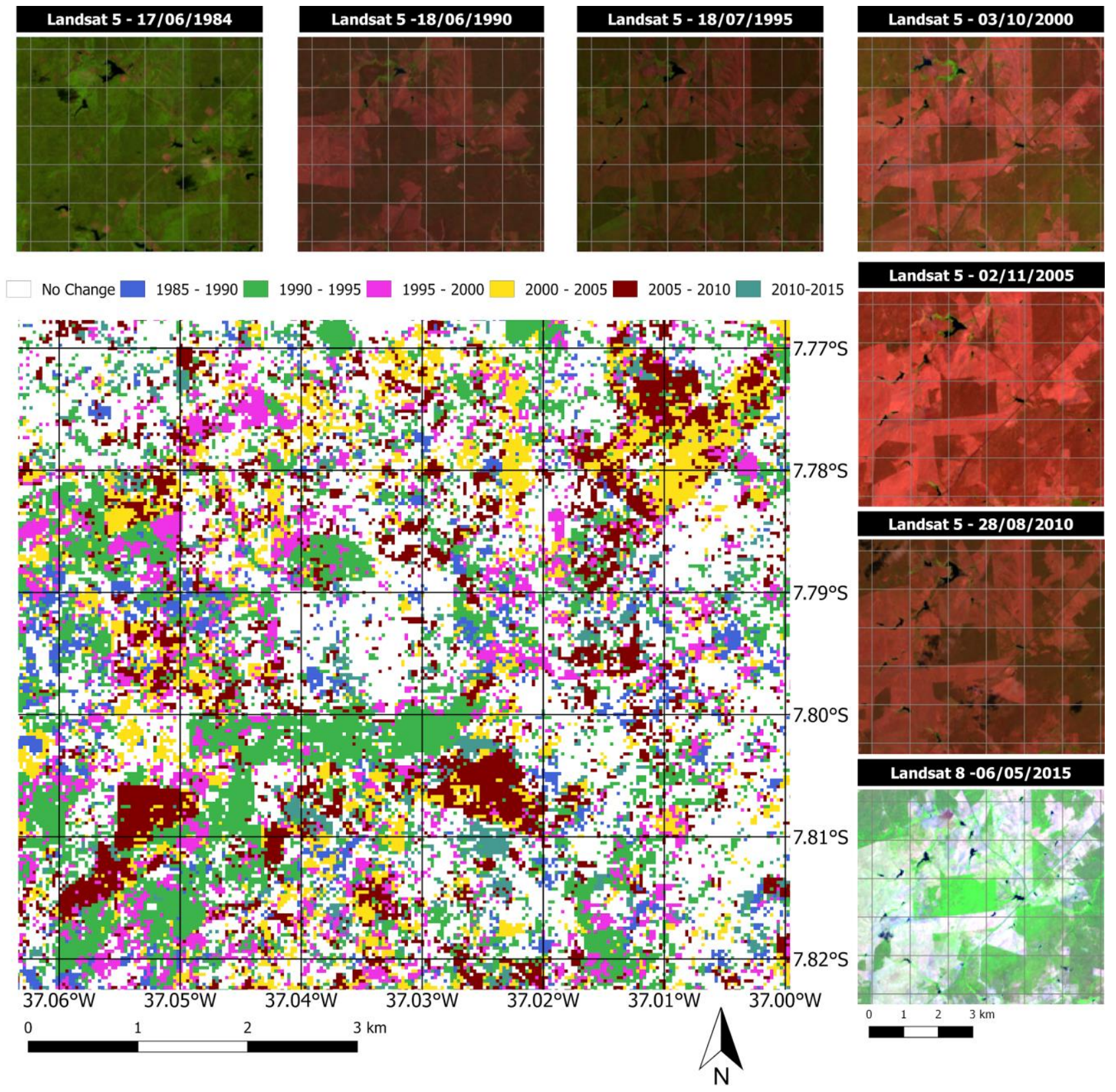

449

Fig. 9 - Estimated LCC year by the TSS-RESTREND method applied to the SA time series for the Subset

450 II highlighted in Fig. 3. Images' source: Landsat 5 (RGB to 4, 3 and 2) and Landsat 8 (RGB to 5, 4 and

$4513)$ false color composite. 
[This is a post-referring version]

[Accepted in Remote Sensing of Environment]

[DOI: 10.1016/j.rse.2019.111250]

[Link to the published paper: https://doi.org/10.1016/i.rse.2019.111250]

452

453

454

455

456

457

458

459

460

461

462

463

464

465

466

467

468

469

470

471

472

473

474
5. Discussion

Our study suggests that in the seasonally dry forests, especially the Brazilian Caatinga, neither EVI nor NDVI are reliable spectral indices for identifying LCC due to difficulties distinguishing deciduous vegetation from the underlying ground by indices that use the VIS-NIR domain (Jacques et al., 2014; Mayes et al., 2015) during the dry period. Despite the wide acceptance of using EVI (Dutrieux et al., 2015) and NDVI (Leroux et al., 2017) to distinguish the effects of climate variability from anthropogenic actions on changes in land cover, these indices exhibited a low performance in detecting the correct timing of the LCC, as suggested by the TSS-RESTREND method. Furthermore, for EVI and NDVI a high number of false negatives (cf. Table 2, Figs. 6 and $7 \mathrm{~A}$ ), and the matching between actual and estimated LCC years were less than $25 \%$, which is far from an acceptable standard for detecting changes in land cover (Aguirre-Gutiérrez et al., 2012; Mas, 1999).

The climate variability has a strong influence on EVI and NDVI in seasonally dry forests (Guan et al 2015; Walker et al, 2015). Despite the TSS-RESTREND method providing an approach to remove the effect of precipitation seasonality from the indices, these vegetation indices still show an effect due to extended drought periods. The years with the most severe droughts in the time series were 1990, 1993, 1998, and 2012. When the LCC occurred in close proximity to these years, EVI and NDVI exhibited a circumstantial good efficiency in identifying LCC, which was the case in 1990 and, especially, 2012. While 2011 was a wet year (maximum SPEI > 2.4), 2012 was the beginning of an extremely dry period, under drought conditions (SPEI $<-0.5)$ and with rainfall amounts below the total average (see Fig. 2). 
[This is a post-referring version]

[Accepted in Remote Sensing of Environment]

[DOI: 10.1016/j.rse.2019.111250]

[Link to the published paper: https://doi.org/10.1016/i.rse.2019.111250]

SA exhibited a greater sensitivity to changes involving characteristics other than the greenness of leaves because this index covers other bands (SWIR 1 and SWIR 2) of the electromagnetic spectrum (Lui et al., 2017; Zhao et al., 2018), which are not used by indices that use VIS-NIR. When a soil-plant-atmosphere system is altered by an action of deforestation, the leafless woody biomass, which represents ca. $95 \%$ of the aboveground biomass in the Caatinga (Silva and Sampaio, 2008), is removed and consequently causes the total exposure of the soil to the effects of microclimate, especially radiation, which can be detected by the SA. This response of the SA due to LCC manifests regardless of the leaf status in the Caatinga. When the leafless Caatinga vegetation is cleared, the Caatinga still loses its interseasonal shrub structure, which causes abrupt and major decreases in surface roughness. As a consequence of the LCC, the light attenuation, represented by the light extinction coefficient and known to be substantial for deciduous shrublands (Aubin et al., 2000; Domingo et al., 2000), is drastically decreased. By contrast, we could not identify any pattern for the low performance in the detection of LCC for EVI and NDVI apart from the climate. For these two indices, the estimated LCC year is often confined to a moment near very dry periods. For example, 1990 was the first year with severe drought conditions in our time series, and it was the estimated LCC year by either EVI or NDVI for target points $3,14,19,28$ and 38 , although no LCC actually occurred in these areas.

Since soil moisture has a high influence on SA, the spectral signals from dry and wet bare soil from any same site can be significantly different (He et al., 2014; Matthias et al., 2000). Therefore, the variation of SA values should be interpreted with 
[This is a post-referring version]

[Accepted in Remote Sensing of Environment]

[DOI: 10.1016/j.rse.2019.111250]

[Link to the published paper: https://doi.org/10.1016/i.rse.2019.111250]

498

499

500

501

502

503

504

505

506

507

508

509

510

511

512

513

514

515

516

517

518

519

520

caution when addressing LCC analysis. Like in most of the Caatinga region, the soils of our study area are shallow and present a low water storage capacity (Medeiros et al., 2018). When the land cover is cleared, the root zone storage is reduced, and, as a result, SA increases. However, in soils with greater depth and water retention capacities, SA may present lower performance as an indicator of LCC. Spectral indices that use the NIR and the SWIR bands also show a better ability to detect plant phenology than that of NDVI and EVI (Jin et al., 2013) by being more sensitive to the water content of vegetation and soil (Rodríguez-Caballero et al., 2015, Zhao et al., 2018). The spectral band SWIR provides a robust way to estimate the extent of bare soil and vegetation cover in arid and semi-arid regions (Asner and Lobell, 2000). Indices that use the SWIR domain, such as the Soil Tillate Index (STI) and Tasseled Cap Wetness (TCW), showed good performance to identify the variance of dry masses in the Sahel (Jacques et al., 2014) and LCC processes in southern Ethiopia (DeVries et al., 2015). We ascribe to soil moisture the cause of the errors in detecting the actual LCC year when using SA for the target areas 25 and 26. A substantial part of these two areas are covered by ephemeral stream beds. Despite exhibiting no surface water most of the years, the stream beds are known for acting as small aquifers by storing water in the alluvial deposits and increasing the soil moisture along stream channels (Fontes Junior and Montenegro, 2017).

The SA exhibited a high performance in detecting LCC $(61 \%)$ or the lack of it (79\%), totalling an overall accuracy of $89 \%$ for all 45 target areas. For the target areas where the LCC was detected, $39 \%$ of them were time wrong and only $6 \%$ were false negatives. We attribute the imprecision in identifying the actual LCC year to some 
[This is a post-referring version]

[Accepted in Remote Sensing of Environment]

[DOI: 10.1016/j.rse.2019.111250]

[Link to the published paper: https://doi.org/10.1016/..rse.2019.111250]

521 adverse effects of the ecosystem response to LCC on the SA. After vegetation

522 removal, the remaining plant ecosystem, i.e., underground roots and soil, needs some

523 time to adapt to the new conditions (Saco et al., 2018), which can cause a gradual loss

524 of the root zone storage (D'Odorico et al., 2013), and, consequently, a delay in the full

525 bare soil SA response, which in turn will cause a time wrong for the estimated LCC year that is after the actual one. Another aspect to consider is that some LCC activities in the Caatinga occur at very small scales (e.g. activities on one-man farms) and they might overlap two consecutive years until the disturbance in the target's SA exceed a threshold that will qualify as a breakpoint in the time series analysis (Pinheiro et al., 2013). We believe that the target areas 9, 10, 20 and 24 exhibit a 1-year delay for the detection of the actual LCC year. These four areas are located in the upper-left quadrant in Fig. 3, and their LCC occured between 1988 and 1993, which was a period when this area was densely vegetated and its land cover was cleared after a highly fragmented LCC process (see Fig. 9). If this 1-year delay is added to the confidence interval of the estimated LCC years, the rate of the time wrong rate is reduced from 39 to $26 \%$. This is a decrease of $40 \%$ in the time wrong estimates, whereas the same 1 year delay tolerance only reduces $20 \%$ and $9 \%$ of EVI and NDVI time wrong LCC estimates, respectively.

The TSS-RESTREND method was built upon two previous approaches to the analysis of changes in land cover, i.e., BFAST and RESTREND, taking advantage of their individual skills in one robust method. We used the structural change component of the TSS-RESTREND, which has three main characteristics that were fundamental to identify an efficient indicator of LCC in the Caatinga: the ability to (i) remove the 
[This is a post-referring version]

[Accepted in Remote Sensing of Environment]

[DOI: 10.1016/j.rse.2019.111250]

[Link to the published paper: https://doi.org/10.1016/i.rse.2019.111250]

544

545

influence in the process of the main climatic variable, the precipitation, (ii) detect, within the time series, structural significant changes in land cover, and (iii) select the most significant of such changes. The TSS-RESTREND, a method conceived, developed and validated to be used with vegetation indices, was evidenced as an efficient approach to be used with SA. The combination of the TSS-RESTREND and SA was appropriate to identify LCC in our Caatinga study area, where the clearing was followed by subsistence farming or livestock occupation with only few underbrush or grass that sustained the higher SA response, qualifying the clearing as the most significant breakpoint in the time series analysis of the TSS-RESTREND. The slow reestablishment of native vegetation on bare soil areas upon abandonment is due to the low natural fertility condition of the shallow, heterogeneous soils of the Caatinga (Salcedo et al., 1997; Sobrinho et al, 2016) and adverse climate (Althoff et al., 2016)

The two false negatives (in the target areas 2 and 21) detected by the SA represented areas that had their vegetation removed in either the first or last five years of the time series, i.e., 1985-1990 and 2010-2015. In these intervals, when using SA, the TSS-RESTREND method shows limitations in establishing a breakpoint. As in other time series analysis methods, errors at the beginning and at the end of any finitelength time series is a common issue (Torrence and Compo, 1998). The statistical theory that supports BFAST (Bai, 1997; Verbesselt et al., 2010), one of the main components of the TSS-RESTREND, requires that a minimum amount of data is set between successive breakpoints and at the beginning and the end of the times series to be able to identify a structural change. Besides, the conclusion of a statistical hypothesis test (e.g., the Chow test) based on a small sample can be unreliable 
[This is a post-referring version]

[Accepted in Remote Sensing of Environment]

[DOI: 10.1016/j.rse.2019.111250]

[Link to the published paper: https://doi.org/10.1016/i.rse.2019.111250]

567

568

569

570

571

572

573

574

575

576

577

578

579

580

581

582

583

584

585

586

587

588

589

because the null hypothesis (corresponding to a non-significant breakpoint) will hardly be rejected at the standard significance levels. Therefore, the use of long time series is essential to reduce these types of uncertainties. In our study, most of the LCC occurred in the 1990s after the first five years of the time series. The Landsat dataset was a valuable source of information by providing long time series where these LCC processes could be evaluated free from these edge effects.

Our study supports further research towards a better understanding of Caatinga land-cover dynamics. When considering the scale at which these biophysical variations can impact large ecosystem extensions such as the Caatinga, not only the carbon balance is affected, but also the energy and water balances (Bonan, 2008). Although the LCC causes a radiative cooling effect due to the increase of SA, this is unbalanced by the associated decrease in evapotranspiration and in surface roughness (Sanderson et al., 2012), which has consequences to regional and global climate, as evidenced by model experiments (Perugini et al., 2017). Based on our work, further analysis and developments in this direction should consider: (i) a deep analysis of SA and other spectral bands applications in LCC studies in other seasonal tropical dry forests; (ii) a cross-related analysis of SA and other variables, such as biomass, evapotranspiration and soil moisture, supported by remote sensing data, and; (iii) the suitability of TSS-RESTREND method in identifying other type of land-cover change processes, such as degradation and fragmentation, not directly covered in our study.

6. Conclusions

We applied SA, EVI and NDVI to the TSS-RESTREND method by using a 31year Landsat time series to evaluate the performance of these indices to detect LCC 
[This is a post-referring version]

[Accepted in Remote Sensing of Environment]

[DOI: 10.1016/j.rse.2019.111250]

[Link to the published paper: https://doi.org/10.1016/i.rse.2019.111250]

590

591

in the Brazilian Caatinga, a tropical seasonally dry forest. We found that SA exhibited a higher accuracy than the EVI and NDVI, and that the structural change detection component of the TSS-RESTREND method was appropriate to identify the LCC.

The spatial resolution and long-term series of the Landsat images allowed a systematic assessment of altered targets on the land surface, laid out in a complex and fragmented pattern characteristic of the anthropogenic LCC in our studied area. TSS-RESTREND showed a satisfactory performance in using long-term satellite data to identify LCC in the Caatinga. The concept of this method is compatible with the reality of the land cover dynamics in this seasonally dry forest, since the selection of the most significant breakpoint unveils the LCC without subsequent vegetation reestablishment. We found some imprecision in the method to identify LCC with a false negative in the first and last few years of the time series (i.e., 1985-1990 and 20102015).

For the two different validation datasets used in this study (target areas and subset I), the SA presented an overall better performance than NDVI and EVI, being able to detect LCC with an acceptable accuracy. The lower performance of the EVI and NDVI indices in the detection of LCC in the Caatinga is explained by their high sensitivity to leaf cover variations as a result of seasonal or extreme dry conditions. Changes in land cover affect the entire soil-plant-atmosphere system, such as removal of biomass and changes in soil properties, as well as in the microclimate, due to direct exposure to radiation, precipitation and wind. Based on those changes, studies should not rely only on vegetation indices but also look for other spectral ranges that will better represent the peculiar characteristics of specific ecosystems. 
[This is a post-referring version]

[Accepted in Remote Sensing of Environment]

[DOI: 10.1016/j.rse.2019.111250]

[Link to the published paper: https://doi.org/10.1016/i.rse.2019.111250]

613

614

615

616

617

618

619

620

621

622

623

624

625

626

627

628

629

630

631

632

633

634

635

636

637

638

639

640

641

642

643

Acknowledgments

This work has been funded by the Brazilian National Council for Scientific and Technological Development (grant numbers 490115/2013-6 and 310789/2016-8) and the European Commission (grant number FP7-614048) through the EUBrazilCC project (http://eubrazilcloudconnect.eu/), CAPES-ANA (grant number 88887.115880/2015-01), and CAPES/PDSE (grant number 88881.134740/2016-01).

This work also forms part of the UK/Brazil Nordeste project funded jointly through the UK Natural Environment Research Council (NE/N012526/1 ICL and NE/N012488/1 UoR) and the Fundação de Amparo à Pesquisa do Estado de São Paulo (2015/504885). We would like to thank the constructive feedback from the reviewers. The Forest Research Centre (CEF) is a research unit funded by Fundação para a Ciência e a Tecnologia I.P. (FCT), Portugal (UID/AGR/00239/2013).

\section{References}

Aguirre-Gutiérrez, J., Seijmonsbergen, A.C., Duivenvoorden, J.F., 2012. Optimizing land cover classification accuracy for change detection, a combined pixel-based and object-based approach in a mountainous area in Mexico. Appl. Geogr. 34, 29-37. doi:10.1016/j.apgeog.2011.10.010

Albuquerque, U.P., de Lima Araújo, E., El-Deir, A.C.A., de Lima, A.L.A., Souto, A., Bezerra, B.M., Ferraz, E.M.N., Maria Xavier Freire, E., Sampaio, E.V. de S.B., Las-Casas, F.M.G., de Moura, G.J.B., Pereira, G.A., de Melo, J.G., Alves Ramos, M., Rodal, M.J.N., Schiel, N., de Lyra-Neves, R.M., Alves, R.R.N., de Azevedo-Júnior, S.M., Telino Júnior, W.R., Severi, W., 2012. Caatinga Revisited: Ecology and Conservation of an Important Seasonal Dry Forest, The Scientific World Journal. doi:10.1100/2012/205182

Alvares, C.A., Stape, J.L., Sentelhas, P.C., De Moraes Gonçalves, J.L., Sparovek, G., 2013. Köppen's climate classification map for Brazil. Meteorol. Zeitschrift 22, 711-728. doi:10.1127/0941-2948/2013/0507

Althoff, T. D., Menezes, R. S. C., de Carvalho, A. L., de Siqueira Pinto, A., Santiago, G. A. C. F., Ometto, J. P. H. B., Sampaio, E. V. (2016). Climate change impacts on the sustainability of the firewood harvest and vegetation and soil carbon stocks in a tropical 
[This is a post-referring version]

[Accepted in Remote Sensing of Environment]

[DOI: 10.1016/j.rse.2019.111250]

[Link to the published paper: https://doi.org/10.1016/i.rse.2019.111250]

644

645

646

647

648

649

650

651

652

653

654

655

656

657

658

659

660

661

662

663

664

665

666

667

668

669

670

671

672

673

674

675

676

677

678

679

680

681 dry forest in Santa Teresinha Municipality, Northeast Brazil. Forest Ecology and Management, 360, 367-375. doi:10.1016/j.foreco.2015.10.001

Andrade-Lima, D, 1981. The caatinga dominium. Revista brasileira de Botânica, 4, 149-163.

Andrade-Silva, A.C.R., Nemésio, A., de Oliveira, F.F., Nascimento, F.S., 2012. Spatial-Temporal Variation in Orchid Bee Communities (Hymenoptera: Apidae) in Remnants of Arboreal Caatinga in the Chapada Diamantina Region, State of Bahia, Brazil. Neotrop. Entomol. 41, 296-305. doi:10.1007/s13744-012-0053-9

Anyamba, A., Small, J.L., Tucker, C.J., Pak, E.W., 2014. Thirty-two Years of Sahelian Zone Growing Season Non-Stationary NDVI3g Patterns. Remote Sens. 6, 3101-3122. doi:10.3390/rs6043101

Araújo, E.L., Castro, C.C., Albuquerque, U.P., 2007. Dynamics of Brazilian Caatinga - A Review Concerning the Plants, Environment and People. Funct. Ecosyst. Communities 1, 15-28.

Araújo, V.F.P., Bandeira, a G., Vasconcellos, a, 2010. Abundance and stratification of soil macroarthropods in a Caatinga Forest in Northeast Brazil. Braz. J. Biol. 70, 737-46. doi:10.1590/S1519-69842010000400006

Asner, G. P., \& Lobell, D. B. (2000). A Biogeophysical Approach for Automated SWIR Unmixing of Soils and Vegetation. Remote Sensing of Environment, 74(1), 99-112. doi:10.1016/s0034-4257(00)00126-7

Aubin, I., Beaudet, M., Messier, C., 2000. Light extinction coefficients specific to the understory vegetation of the southern boreal forest, Quebec Can. J. For. Res. 30: 168177

Bai, J., 1997. Estimation of a Change Point in Multiple Regression Models. Rev. Econ. Stat. 79, 551-563. doi:10.1162/003465397557132

Begueria, S., Latorre, B., Reig, F., Vicente-Serrano, S.M. 2017. Global SPEI database. http://spei.csic.es/database.html. Access in 11 January 2017.

Belchior, M., Tai, D.W., Held, F.C. Von, 2017. Indicadores IBGE. Inst. Bras. Geogr. E Estatística - lbge 6.

Bonan, G. B., (2008) Forests and climate change: Forcings, feed- backs, and the climate benefits of forests. Science, 320, 1444-1449, doi:10.1126/science.1155121.

Brito, A.F., Presley, S.J., Santos, G.M.M., 2012. Temporal and trophic niche overlap in a guild of flower-visiting ants in a seasonal semi-arid tropical environment, Journal of Arid Environments. doi:10.1016/j.jaridenv.2012.07.001

Burrell, A.L., Evans, J.P., Liu, Y., 2017. Detecting dryland degradation using Time Series Segmentation and Residual Trend analysis (TSS-RESTREND). Remote Sens. Environ. doi:10.1016/j.rse.2017.05.018

Burrell, A.L., Evans, J.P., Liu, Y., 2018. The impact of dataset selection on land degradation assessment. ISPRS J. Photogramm. Remote Sens. 146, 22-37. doi: 10.1016/j.isprsjprs.2018.08.017 
[This is a post-referring version]

[Accepted in Remote Sensing of Environment]

[DOI: 10.1016/j.rse.2019.111250]

[Link to the published paper: https://doi.org/10.1016/i.rse.2019.111250]

682

683

684

685

686

687

688

689

690

691

692

693

694

695

696

697

698

699

700

701

702

703

704

705

706

707

708

709

710

711

712

713

714

715

716

717

718

719

Cadier, E. 1996. Small watershed hydrology in semi-arid north-eastern Brazil: basin typology and transposition of annual runoff data. Journal of Hydrology, 182(1-4), 117-141. doi: 10.1016/0022-1694(95)02933-8

Cao, R., Chen, Y., Shen, M., Chen, J., Zhou, J., Wang, C., \& Yang, W. 2018. A simple method to improve the quality of NDVI time-series data by integrating spatiotemporal information with the Savitzky-Golay filter. Remote Sensing of Environment, 217, 244-257. doi:10.1016/j.rse.2018.08.022

Chen, J., Jönsson, P., Tamura, M., Gu, Z., Matsushita, B., Eklundh, L., 2004. A simple method for reconstructing a high-quality NDVI time-series data set based on the Savitzky-Golay filter. Remote Sens. Environ. 91, 332-344. doi:10.1016/j.rse.2004.03.014

Chow, G.C., 1960. Tests of equality between sets of coefficients in two linear regressions. Econometrica 28:591-605. doi:10.2307/1910133.

CNUC - Cadastro Nacional de Unidades de Conservação (Brazilian National Database of Conservation Units). Accessed in oct-2018

D’Odorico, P., Bhattachan, A., Davis, K.F., Ravi, S., Runyan, C.W., 2013. Global desertification: Drivers and feedbacks. Adv. Water Resour. 51, 326-344. doi:10.1016/j.advwatres.2012.01.013

Daughtry, C.S.T., 2001. Discriminating Crop Residues from Soil by Shortwave Infrared Reflectance. Agron. J. 93, 125. doi:10.2134/agronj2001.931125x

De Jong, R., Verbesselt, J., Schaepman, M.E., de Bruin, S., 2012. Trend changes in global greening and browning: Contribution of short-term trends to longer-term change. Glob. Chang. Biol. doi:10.1111/j.1365-2486.2011.02578.x

DeVries, B., Verbesselt, J., Kooistra, L., Herold, M., 2015. Robust monitoring of small-scale forest disturbances in a tropical montane forest using Landsat time series. Remote Sens. Environ. doi:10.1016/j.rse.2015.02.012

Domingo, F., Villagarcia, L., Brenner, A. J., \& Puigdefabregas, J. 2000. Measuring and modelling the radiation balance of a heterogeneous shrubland. Plant, Cell and Environment, 23(1), 27-38. doi:10.1046/j.1365-3040.2000.00532.x

Dutrieux, L.P., Verbesselt, J., Kooistra, L., Herold, M., 2015. Monitoring forest cover loss using multiple data streams, a case study of a tropical dry forest in Bolivia. ISPRS J. Photogramm. Remote Sens. doi:10.1016/j.isprsjprs.2015.03.015

Dwyer, J., Roy, D., Sauer, B., Jenkerson, C., Zhang, H., Lymburner, L., 2018. Analysis Ready Data: Enabling Analysis of the Landsat Archive 1-24. doi:10.20944/PREPRINTS201808.0029.V1

Eckert, S., Hüsler, F., Liniger, H., Hodel, E., 2015. Trend analysis of MODIS NDVI time series for detecting land degradation and regeneration in Mongolia. J. Arid Environ. 113, 16-28. doi:10.1016/j.jaridenv.2014.09.001

Egorov, A. V., Roy, D.P., Zhang, H.K., Hansen, M.C., Kommareddy, A., 2018. Demonstration of 
[This is a post-referring version]

[Accepted in Remote Sensing of Environment]

[DOI: 10.1016/j.rse.2019.111250]

[Link to the published paper: https://doi.org/10.1016/i.rse.2019.111250]

percent tree cover mapping using Landsat Analysis Ready Data (ARD) and sensitivity with respect to Landsat ARD processing level. Remote Sensing 10. doi:10.3390/rs10020209

Erasmi, S., Schucknecht, A., Barbosa, M.P., Matschullat, J., 2014. Vegetation greenness in northeastern brazil and its relation to ENSO warm events. Remote Sens. 6, 3041-3058. doi:10.3390/rs6043041

Evans, J., Geerken, R., 2004. Discrimination between climate and human-induced dryland degradation. J. Arid Environ. 57, 535-554. doi:10.1016/S0140-1963(03)00121-6

Fensholt, R., Langanke, T., Rasmussen, K., Reenberg, A., Prince, S.D., Tucker, C., Scholes, R.J., Le, Q.B., Bondeau, A., Eastman, R., Epstein, H., Gaughan, A.E., Hellden, U., Mbow, C., Olsson, L., Paruelo, J., Schweitzer, C., Seaquist, J., Wessels, K., 2012. Greenness in semiarid areas across the globe 1981-2007 - an Earth Observing Satellite based analysis of trends and drivers. Remote Sensing of Environment. 121, 144-158. doi:10.1016/j.rse.2012.01.017

Flood, N., 2013. Seasonal composite Landsat TM/ETM+ Images using the medoid (a multidimensional median). Remote Sens. 5, 6481-6500. doi:10.3390/rs5126481

Fontes Júnior, R.V. de P., Montenegro, A.A. de A., 2017. Temporal dependence of potentiometric levels and groundwater salinity in alluvial aquifer upon rainfall and evapotranspiration. Rbrh 22. doi:10.1590/2318-0331.0217170059

Funk, C., Peterson, P., Landsfeld, M., Pedreros, D., Verdin, J., Shukla, S., Husak, G., Rowland, J., Harrison, L., Hoell, A., Michaelsen, J., 2015. The climate hazards infrared precipitation with stations-a new environmental record for monitoring extremes. Sci. Data 2, 150066. doi:10.1038/sdata.2015.66

Gómez, C., White, J.C., Wulder, M.A., 2016. Optical remotely sensed time series data for land cover classification: A review. ISPRS Journal of Photogrammetry and Remote Sensing. doi:10.1016/j.isprsjprs.2016.03.008

Guan, K., Pan, M., Li, H., Wolf, A., Wu, J., Medvigy, D., Caylor, K.K., Sheffield, J., Wood, E.F., Malhi, Y., Liang, M., Kimball, J.S., Saleska, S.R., Berry, J., Joiner, J., Lyapustin, A.I., 2015. Photosynthetic seasonality of global tropical forests constrained by hydroclimate. Nat. Geosci. 8, 284-289. doi:10.1038/ngeo2382

He, C., Tian, J., Gao, B., Zhao, Y., 2015. Differentiating climate and human-induced drivers of grassland degradation in the Liao River Basin, China. Environ. Monit. Assess. 187, 4199. doi:10.1007/s10661-014-4199-2

Hein, L., De Ridder, N., Hiernaux, P., Leemans, R., De Wit, A., Schaepman, M., 2011. Desertification in the Sahel: Towards better accounting for ecosystem dynamics in the interpretation of remote sensing images. Journal of Arid Environments. 75, 1164-1172. doi:10.1016/j.jaridenv.2011.05.002

Helsel, D.R., Hirsch, R.M., 2002. Trend Analysis. Stat. Methods Water Resour. Tech. Water Resour. Investig. B. 4, chapter A3 323-355.

Higginbottom, T.P., Symeonakis, E., 2014. Assessing land degradation and desertification using 
[This is a post-referring version]

[Accepted in Remote Sensing of Environment]

[DOI: 10.1016/j.rse.2019.111250]

[Link to the published paper: https://doi.org/10.1016/i.rse.2019.111250]

vegetation index data: Current frameworks and future directions. Remote Sens. 6, 95529575. doi:10.3390/rs6109552

Holben, B.N., 1986. Characteristics of maximum-value composite images from temporal AVHRR data. Int. J. Remote Sens. 7, 1417-1434. doi:10.1080/01431168608948945

Huete, A., Didan, K., Miura, T., Rodriguez, E.P., Gao, X., Ferreira, L.G., 2002. Overview of the radiometric and biophysical performance of the MODIS vegetation indices. Remote Sens. Environ. 83, 195-213. doi:10.1016/S0034-4257(02)00096-2

Huete, A.R., Liu, H.Q., Batchily, K., J., L. van W., 1997. A comparison of vegetation indices over a global set of TM images for EOS-MODIS. Remote Sensing of Environment, 59(3), 440451. doi:10.1016/s0034-4257(96)00112-5.

Ibrahim, Y.Z., Balzter, H., Kaduk, J., Tucker, C.J., 2015. Land degradation assessment using residual trend analysis of GIMMS NDVI3g, soil moisture and rainfall in Sub-Saharan West Africa from 1982 to 2012. Remote Sens. 7, 5471-5494. doi:10.3390/rs70505471

IPCC. Intergovernmenta Panel Climate Change http://www.ipcc.ch/ipccreports/sres/land_use/index.php?idp=157. Accessed in oct2018

Jacques, D.C., Kergoat, L., Hiernaux, P., Mougin, E., Defourny, P., 2014. Monitoring dry vegetation masses in semi-arid areas with MODIS SWIR bands. Remote Sens. Environ. 153, 40-49. doi:10.1016/j.rse.2014.07.027

Jamali, S., Jönsson, P., Eklundh, L., Ardö, J., Seaquist, J., 2015. Detecting changes in vegetation trends using time series segmentation. Remote Sens. Environ. 156, 182-195. doi:10.1016/j.rse.2014.09.010

Jin, C., Xiao, X., Merbold, L., Arneth, A., Veenendaal, E., Kutsch, W.L., 2013. Phenology and gross primary production of two dominant savanna woodland ecosystems in Southern Africa. Remote Sens. Environ. 135, 189-201. doi:10.1016/j.rse.2013.03.033

Ju, J., Masek, J.G., 2016. The vegetation greenness trend in Canada and US Alaska from 19842012 Landsat data. Remote Sensing of Environment. doi:10.1016/j.rse.2016.01.001

Karlson, M., Ostwald, M., 2016. Remote sensing of vegetation in the Sudano-Sahelian zone: A literature review from 1975 to 2014. J. Arid Environ. doi:10.1016/j.jaridenv.2015.08.022

Karnieli, A., Qin, Z., Wu, B., Panov, N., Yan, F., 2014. Spatio-temporal dynamics of land-use and land-cover in the Mu Us Sandy Land, China, using the change vector analysis technique. Remote Sens. 6, 9316-9339. doi:10.3390/rs6109316

Katsanos, D., Retalis, A., Michaelides, S., 2016. Validation of a high-resolution precipitation database (CHIRPS) over Cyprus for a 30-year period. Atmos. Res. 169, 459-464. doi:10.1016/j.atmosres.2015.05.015

Lambin, E.F., Geist, H.J., Lepers, E., 2003. Dynamics of land use and land cover change in tropical regions. Annu. Rev. Environ. Resour. 28, 205-241. doi:10.1146/annurev.energy.28.050302.105459 
[This is a post-referring version]

[Accepted in Remote Sensing of Environment]

[DOI: 10.1016/j.rse.2019.111250]

[Link to the published paper: https://doi.org/10.1016/i.rse.2019.111250]

797

798

799

800

801

802

803

804

805

806

807

808

809

810

811

812

813

814

815

816

817

818

819

820

821

822

823

824

825

826

827

828

829

830

831

832

833

834

835

Lamchin, M., Lee, J.Y., Lee, W.K., Lee, E.J., Kim, M., Lim, C.H., Choi, H.A., Kim, S.R., 2016. Assessment of land cover change and desertification using remote sensing technology in a local region of Mongolia. Adv. Sp. Res. 57, 64-77. doi:10.1016/j.asr.2015.10.006

Le Toan, T., Quegan, S., Davidson, M.W.J., Balzter, H., Paillou, P., Papathanassiou, K., Plummer, S., Rocca, F., Saatchi, S., Shugart, H., Ulander, L., 2011. The BIOMASS mission: Mapping global forest biomass to better understand the terrestrial carbon cycle. Remote Sens. Environ. 115, 2850-2860. doi:10.1016/j.rse.2011.03.020

Leal, I.R., Da Silva, J.M.C., Tabarelli, M., Lacher, T.E., 2005. Changing the Course of Biodiversity Conservation in the Caatinga of Northeastern Brazil \rCambiando el Curso de la Conservación de Biodiversidad en la Caatinga del Noreste de Brasil. Conserv. Biol. 19, 701-706. doi:10.1111/j.1523-1739.2005.00703.x

Leroux, L., Bégué, A., Lo Seen, D., Jolivot, A., Kayitakire, F., 2017. Driving forces of recent vegetation changes in the Sahel: Lessons learned from regional and local level analyses. Remote Sens. Environ. 191, 38-54. doi:10.1016/j.rse.2017.01.014

Li, X.B., Li, R.H., Li, G.Q., Wang, H., Li, Z.F., Li, X., Hou, X.Y., 2016. Human-induced vegetation degradation and response of soil nitrogen storage in typical steppes in Inner Mongolia, China. Journal of Arid Environments. doi:10.1016/j.jaridenv.2015.07.013

Lima, A.L.A., Rodal, M.J.N., 2010. Phenology and wood density of plants growing in the semiarid region of northeastern Brazil, Journal of Arid Environments. doi:10.1016/j.jaridenv.2010.05.009

Lima, G.D.S., Lima, J.R. de F., Silva, N. da, Oliveira, R.S. de, Lucena, R.F.P., 2016. Inventory in situ of plant resources used as fuel in the Semiarid Region of Northeast Brazil. Brazilian J. Biol. Sci. 3, 45. doi:10.21472/bjbs.030505

Linares-Palomino, R., Oliveira-Filho, A.T., Pennington, R.T., 2011. Seasonally Dry Tropical Forests 3-21. doi:10.5822/978-1-61091-021-7

Liu, F., Chen, Y., Lu, H., Shao, H., 2017. Albedo indicating land degradation around the Badain Jaran Desert for better land resources utilization. Sci. Total Environ. 578, 67-73. doi:10.1016/j.scitotenv.2016.06.171

Liu, J., Shao, Q., Yan, X., Fan, J., Zhan, J., Deng, X., Huang, L, 2016. The climatic impacts of land use and land cover change compared among countries. Journal of Geographical Sciences, 26(7), 889-903. doi: 10.1007/s11442-016-1305-0

Loveland, T.R., Dwyer, J.L., 2012. Landsat: Building a strong future. Remote Sensing of Environment. 122, 22-29. doi:10.1016/j.rse.2011.09.022

Marengo, J.A., Torres, R.R., Alves, L.M., 2017. Drought in Northeast Brazil-past, present, and future. Theor. Appl. Climatol. 129, 1189-1200. doi:10.1007/s00704-016-1840-8

Mariano, D.A., Santos, C.A.C. do., Wardlow, B.D., Anderson, M.C., Schiltmeyer, A. V., Tadesse, T., Svoboda, M.D., 2018. Use of remote sensing indicators to assess effects of drought and human-induced land degradation on ecosystem health in Northeastern Brazil. 
[This is a post-referring version]

[Accepted in Remote Sensing of Environment]

[DOI: 10.1016/j.rse.2019.111250]

[Link to the published paper: https://doi.org/10.1016/i.rse.2019.111250]

Remote Sens. Environ. 213, 129-143. doi:10.1016/j.rse.2018.04.048

Mas, 1999. International Journal of Monitoring land-cover changes : A comparison of change detection techniques. Int. J. Remote Sens. 20, 139-152. doi:10.1080/014311699213659

Masek, J.G., Vermote, E.F., Saleous, N.E., Wolfe, R., Hall, F.G., Huemmrich, K.F., Gao, F., Kutler, J., Lim, T., 2006. A Landsat Surface Reflectance Dataset for North America, 1990-2000. IEEE Geoscience and Remote Sensing Letters, 3(1), 68-72. doi:10.1109/Igrs.2005.857030

Matthias, A.D.D., Fimbres, A., Sano, E.E.E., Post, D.F.F., Accioly, L., Batchily, A.K.K., Ferreira, L.G.G., 2000. Surface roughness effects on soil albedo. Soil Sci. Soc. Am. J. 64, 10351041. doi:10.2136/sssaj2000.6431035x

Mayes, M.T., Mustard, J.F., Melillo, J.M., 2015. Forest cover change in Miombo Woodlands: Modeling land cover of African dry tropical forests with linear spectral mixture analysis. Remote Sens. Environ. 165, 203-215. doi:10.1016/j.rse.2015.05.006

Medeiros, I.C., da Costa Silva, J.F.C.B., Silva, R.M., Santos, C.A.G., 2018. Run-off-erosion modelling and water balance in the Epitácio Pessoa Dam river basin, Paraíba State in Brazil. Int. J. Environ. Sci. Technol. doi:10.1007/s13762-018-1940-3

MMA, Brazilian Ministry of the Environment, 2018. http://geocatalogo.mma.gov.br/

Moro, M.F., Lughadha, E.N., Araújo, F.S. De, Martins, F.R., 2016. A Phytogeographical Metaanalysis of the Semiarid Caatinga Domain in Brazil. Bot. Rev. doi:10.1007/s12229016-9164-z

Moro, M.F., Nic Lughadha, E., de Araújo, F.S, 2016. Bot. Rev. 82: 91. doi: 10.1007/s12229-0169164-z

Munyati, C., Mboweni, G., 2013. Variation in NDVI values with change in spatial resolution for semi-arid savanna vegetation: A case study in northwestern South Africa. Int. J. Remote Sens. 34, 2253-2267. doi:10.1080/01431161.2012.743692

Nagler, P.L., Daughtry, C.S.T., Goward, S.N., 2000. Plant litter and soil reflectance. Remote Sens. Environ. 71, 207-215. doi:10.1016/S0034-4257(99)00082-6

National Institute of Meteorology of Brazil, 2018. Available: http://www.inmet.gov.br/portal/index.php?r=bdmep/bdmep

Nouvelot, J. F. 1974. Planificação da implantação de bacias representativas. Recife, SUDENEDRN.

Padilha, A. L., Vitorello, Í., Pádua, M. B., \& Fuck, R. A, 2016. Deep magnetotelluric signatures of the early Neoproterozoic Cariris Velhos tectonic event within the Transversal subprovince of the Borborema Province, NE Brazil. Precambrian Research, 275, 70-83.

Paredes-Trejo, F.J., Barbosa, H.A., Lakshmi Kumar, T. V., 2017. Validating CHIRPS-based satellite precipitation estimates in Northeast Brazil. J. Arid Environ. 139, 26-40. doi:10.1016/j.jaridenv.2016.12.009

Pereira, I.M., Andrade, L.A., Sampaio, E.V.S.B., Barbosa, M.R. V., 2003. Use-history Effects on 
[This is a post-referring version]

[Accepted in Remote Sensing of Environment]

[DOI: 10.1016/j.rse.2019.111250]

[Link to the published paper: https://doi.org/10.1016/i.rse.2019.111250]

Structure and Flora of Caatinga. Biotropica 35, 154-165. doi:10.1111/j.17447429.2003.tb00275.x

Perez-Marin, Aldrin \& Cavalcante, A.M.B. \& Medeiros, Silvana \& Tinôco, Leonardo \& Salcedo, I.H. 2012. Núcleos de desertificação no semiárido brasileiro: Ocorrência natural ou antrópica?. Parcerias Estratégicas. 17. 87-106.

Perugini, L., Caporaso, L., Marconi, S., Cescatti, A., Quesada, B., de Noblet-Ducoudré, N., ... Arneth, A. 2017. Biophysical effects on temperature and precipitation due to land cover change. Environmental Research Letters, 12(5), 053002. doi: 10.1088/17489326/aa6b3f

Pinheiro, E.A.R., Costa, C.A.G., De Araújo, J.C., 2013. Effective root depth of the Caatinga biome. J. Arid Environ. 89, 1-4. doi:10.1016/j.jaridenv.2012.10.003

R Core Team, 2017. R: A language and environment for statistical computing. R Foundation for Statistical Computing, Vienna, Austria. URL https://www.R-project.org/.

Rodal, M., Barbosa, M., Thomas, W., 2008. Do the seasonal forests in northeastern Brazil represent a single floristic unit? Brazilian J. Biol. 68, 467-475. doi:10.1590/S151969842008000300003

Rodríguez-Caballero, E., Knerr, T., Weber, B., 2015. Importance of biocrusts in dryland monitoring using spectral indices. Remote Sens. Environ. 170, 32-39. doi:10.1016/j.rse.2015.08.034

Saco, P.M., Moreno-de las Heras, M., Keesstra, S., Baartman, J., Yetemen, O., Rodríguez, J.F., 2018. Vegetation and soil degradation in drylands: Non linear feedbacks and early warning signals. Curr. Opin. Environ. Sci. Heal. 5, 67-72. doi:10.1016/j.coesh.2018.06.001

Salcedo, I.H., Tiessen, H., Sampaio, E.V.S.B., 1997. Nutrient availability in, soil samples from shifting cultivation sites in the semi-arid Caatinga of NE Brazil. Agric. Ecosyst. Environ. 65, 177-186. doi:10.1016/S0167-8809(97)00073-X

Samain, O., Kergoat, L., Hiernaux, P., Guichard, F., Mougin, E., Timouk, F., Lavenu, F., 2008. Analysis of the in situ and MODIS albedo variability at multiple timescales in the sahel. J. Geophys. Res. Atmos. 113, 1-16. doi:10.1029/2007JD009174

Sanderson M., Pope E., Santini M., Mercogliano P., Montesarchio, M., 2012 Influences of EU forests on weather patterns: Final Report. Report for the European commission (DGEnvironment). http://ec.europa.eu/environment/forests/pdf/EU_Forests_Final_Report.pdf

Santos, a M., Tabarelli, M., 2002. Distance from roads and cities as a predictor of habitat loss and fragmentation in the caatinga vegetation of Brazil. Braz. J. Biol. 62, 897-905. doi:10.1590/S1519-69842002000500020

Santos, R.M., Oliveira-Filho, A.T., Eisenlohr, P. V., Queiroz, L.P., Cardoso, D.B.O.S., Rodal, M.J.N., 2012. Identity and relationships of the Arboreal Caatinga among other floristic units of seasonally dry tropical forests (SDTFs) of north-eastern and Central Brazil, 
[This is a post-referring version]

[Accepted in Remote Sensing of Environment]

[DOI: 10.1016/j.rse.2019.111250]

[Link to the published paper: https://doi.org/10.1016/i.rse.2019.111250] Ecology and Evolution. doi:10.1002/ece3.91

Savitzky, A., Golay, M.J.E., 1964. Smoothing and Differentiation of Data by Simplified Least Squares Procedures. Anal. Chem. 36, 1627-1639. doi:10.1021/ac60214a047

Schertz, T., Alexander, R., Ohe, D., 1991. The computer program Estimate Trend (ESTREND), a system for the Detection of Trends in Water-quality data 1-63.

Schucknecht, A., Erasmi, S., Niemeyer, I., Matschullat, J., 2013. Assessing vegetation variability and trends in north-eastern Brazil using AVHRR and MODIS NDVI time series. European Journal of Remote Sensing. 46, 40-59. doi:10.5721/EuJRS20134603

Schwinning, S., Sala, O.E., Loik, M.E., 2004 Oecologia 141: 191. doi: 10.1007/s00442-0041683-3

Shuai, Y., Masek, J.G., Gao, F., Schaaf, C.B., 2011. An algorithm for the retrieval of 30-m snowfree albedo from Landsat surface reflectance and MODIS BRDF. Remote Sens. Environ. 115, 2204-2216. doi:10.1016/j.rse.2011.04.019

Shuai, Y., Masek, J.G., Gao, F., Schaaf, C.B., He, T., 2014. An approach for the long-term 30-m land surface snow-free albedo retrieval from historic Landsat surface reflectance and MODIS-based a priori anisotropy knowledge. Remote Sens. Environ. 152, 467-479. doi:10.1016/j.rse.2014.07.009

Silva JMC, Barbosa LCF, Leal, IR. Tabarelli M, 2017 The Caatinga: Understanding the Challenges. Silva JMC, Leal IR, Tabarelli M, editors. Caatinga: the largest tropical dry forest region in South America. Cham: Springer;.doi: 10.1007/978-3-319-68339-3_1

Silva, G.C., Sampaio, E.V.S.B., 2008. Biomassas de partes aéreas em plantas da Caatinga. Soc. Investig. Florestais 32, 567-575. doi:10.1016/j.jaridenv.2015.02.003

Sobrinho, M. S., Tabarelli, M. , Machado, I. C., Sfair, J. C., Bruna, E. M. and Lopes, A. V. 2016. Land use, fallow period and the recovery of a Caatinga forest. Biotropica, 48:586-597. doi:10.1111/btp.12334

Song, X.P., Huang, C., Sexton, J.O., Channan, S., Townshend, J.R., 2014. Annual detection of forest cover loss using time series satellite measurements of percent tree cover. Remote Sensing. 6, 8878-8903. doi:10.3390/rs6098878

Steyaert, L. T., \& Knox, R. G, 2008. Reconstructed historical land cover and biophysical parameters for studies of land-atmosphere interactions within the eastern United States. Journal of Geophysical Research, 113(D2), D02101. doi: 10.1029/2006JD008277

Stroppiana, D., Bordogna, G., Carrara, P., Boschetti, M., Boschetti, L., Brivio, P.A., 2012. A method for extracting burned areas from Landsat TM/ETM+ images by soft aggregation of multiple Spectral Indices and a region growing algorithm. ISPRS J. Photogramm. Remote Sens. 69, 88-102. doi:10.1016/j.isprsjprs.2012.03.001

Torrence, C., Compo, G.P., 1998. A practical guide to wavelet analysis. Bull. Am. Meteor. Soc. 79, 61-78. doi:10.1175/1520-0477(1998)079<0061:APGTWA>2.0.CO;2

Tucker, C.J., 1979. Red and photographic infrared linear combinations for monitoring 
[This is a post-referring version]

[Accepted in Remote Sensing of Environment]

[DOI: 10.1016/j.rse.2019.111250]

[Link to the published paper: https://doi.org/10.1016/i.rse.2019.111250] vegetation. Remote Sens. Environ. 8, 127-150. doi:10.1016/0034-4257(79)90013-0

U.S. Geological Survey, 2018a. Product Guide: LANDSAT 4-7 SURFACE REFLECTANCE (LEDAPS) PRODUCT. Department of the Interior Version 8.3, https://landsat.usgs.gov/sites/default/files/documents/ledaps_product_guide.pdf

U.S. Geological Survey, 2018b. Product Guide: Landsat 8 Surface Reflectance code (LaSRC) product. Department of the Interior Version 4.3, https://landsat.usgs.gov/sites/default/files/documents/lasrc_product_guide.pdf

Velloso, A. L., Sampaio, E. V. S. B., \& Pareyn, F. G. C, 2001. Ecorregiões: propostas para o bioma caatinga; resultados do seminário de planejamento ecorregional da caatinga. Seminário de Planejamento Ecorregional da Caatinga. TNC/APNE Recife, Aldeia-Pernambuco, 76.

Verbesselt, J., Hyndman, R., Newnham, G., Culvenor, D., 2010. Detecting trend and seasonal changes in satellite image time series. Remote Sens. Environ. doi:10.1016/j.rse.2009.08.014

Verbesselt, J., Umlauf, N., Hirota, M., Holmgren, M., Van Nes, E.H., Herold, M., Zeileis, A., Scheffer, M., 2016. Remotely sensed resilience of tropical forests. Nat. Clim. Chang. doi:10.1038/nclimate3108

Verbesselt, J., Zeileis, A., Herold, M., 2012. Near real-time disturbance detection using satellite image time series. Remote Sens. Environ. doi:10.1016/j.rse.2012.02.022

Vermote, E., Justice, C., Claverie, M., Franch, B., 2016. Remote Sensing of Environment Preliminary analysis of the performance of the Landsat 8 / OLI land surface reflectance product. Remote Sens. Environ. doi:10.1016/j.rse.2016.04.008

Vicente-Serrano S.M., Beguería, S. López-Moreno, J.I., 2010. A Multi-scalar drought index sensitive to global warming: The Standardized Precipitation Evapotranspiration Index SPEI. Journal of Climate 23, 1696-1718. https://doi.org/10.1175/2009JCLI2909.1

Walker, J., de Beurs, K., Wynne, R.H., 2015. Phenological response of an Arizona dryland forest to short-term climatic extremes. Remote Sens. 7, 10832-10855. doi:10.3390/rs70810832

Wang, Z., Erb, A.M., Schaaf, C.B., Sun, Q., Liu, Y., Yang, Y., Shuai, Y., Casey, K.A., Román, M.O., 2016. Remote Sensing of Environment Early spring post- fi re snow albedo dynamics in high latitude boreal forests using Landsat-8 OLI data. Remote Sens. Environ. 185, 71-83. doi:http://dx.doi.org/10.1016/j.rse.2016.02.059

Wang, Z., Schaaf, C.B., Sun, Q., Kim, J., Erb, A.M., Gao, F., Román, M.O., Yang, Y., Petroy, S., Taylor, J.R., Masek, J.G., Morisette, J.T., Zhang, X., Papuga, S.A., 2017. Monitoring land surface albedo and vegetation dynamics using high spatial and temporal resolution synthetic time series from Landsat and the MODIS BRDF/NBAR/albedo product. International Journal of Applied Earth Observation and Geoinformation. doi:10.1016/j.jag.2017.03.008

Wessels, K.J., Prince, S.D., Malherbe, J., Small, J., Frost, P.E., VanZyl, D., 2007. Can humaninduced land degradation be distinguished from the effects of rainfall variability? A case 
[This is a post-referring version]

[Accepted in Remote Sensing of Environment]

[DOI: 10.1016/j.rse.2019.111250]

[Link to the published paper: https://doi.org/10.1016/j.rse.2019.111250]

989

990

991

992

993

994

995

996

997

998

999

1000

1001

1002

1003

1004

1005

1006

1007

1008

1009

1010

1011

1012

1013

1014

1015

study in South Africa. J. Arid Environ. 68, 271-297. doi:10.1016/j.jaridenv.2006.05.015

Wessels, K.J., van den Bergh, F., Scholes, R.J., 2012. Limits to detectability of land degradation by trend analysis of vegetation index data. Remote Sens. Environ. 125, 10-22. doi:10.1016/j.rse.2012.06.022

Wulder, M.A., White, J.C., Loveland, T.R., Woodcock, C.E., Belward, A.S., Cohen, W.B., Fosnight, E.A., Shaw, J., Masek, J.G., Roy, D.P., 2016. The global Landsat archive: Status, consolidation, and direction. Remote Sensing of Environment. 185, 271-283. doi:10.1016/j.rse.2015.11.032

Xu, D., Guo, X., Li, Z., Yang, X., Yin, H., 2014. Remote Sensing of Environment Measuring the dead component of mixed grassland with Landsat imagery. Remote Sens. Environ. 142, 33-43. doi:10.1016/j.rse.2013.11.017

Yang, Y., Wang, Z., Li, J., Gang, C., Zhang, Y., Zhang, Y., Odeh, I., Qi, J., 2016. Comparative assessment of grassland degradation dynamics in response to climate variation and human activities in China, Mongolia, Pakistan and Uzbekistan from 2000 to 2013. Journal of Arid Environments. 135, 164-172. doi:10.1016/j.jaridenv.2016.09.004

Yu, Y., Notaro, M., Wang, F., Mao, J., Shi, X., Wei, Y., 2017. Observed positive vegetationrainfall feedbacks in the Sahel dominated by a moisture recycling mechanism. Nat. Commun. 8, 1-9. doi:10.1038/s41467-017-02021-1

Zhang, J., Niu, J.M., Bao, T., Buyantuyev, A., Zhang, Q., Dong, J.J., Zhang, X.F., 2014. Human induced dryland degradation in Ordos Plateau, China, revealed by multilevel statistical modeling of normalized difference vegetation index and rainfall time-series. J. Arid Land 6, 219-229. doi:10.1007/s40333-013-0203-x

Zhao, Y., Wang, X., Novillo, C.J., Arrogante-Funes, P., Vázquez-Jiménez, R., Maestre, F.T., 2018. Albedo estimated from remote sensing correlates with ecosystem multifunctionality in global drylands. J. Arid Environ. 157, 116-123. doi:10.1016/j.jaridenv.2018.05.010 